Portland State University

PDXScholar

1990

\title{
A history of the Sisters of St. Mary of Oregon's mission in Tamshiyacu, Peru 1966-1973
}

Pauline Rose Walbel

Portland State University

Follow this and additional works at: https://pdxscholar.library.pdx.edu/open_access_etds

Part of the History of Religion Commons

Let us know how access to this document benefits you.

\section{Recommended Citation}

Walbel, Pauline Rose, "A history of the Sisters of St. Mary of Oregon's mission in Tamshiyacu, Peru 1966-1973" (1990). Dissertations and Theses. Paper 4132.

https://doi.org/10.15760/etd.6015

This Thesis is brought to you for free and open access. It has been accepted for inclusion in Dissertations and Theses by an authorized administrator of PDXScholar. Please contact us if we can make this document more accessible: pdxscholar@pdx.edu. 
AN ABSTRACT OF THE THESIS OF Sister Pauline Rose Waibel for the Master of Arts in History presented July 16, 1990.

Title: A Hlstory of the Sisters of St. Mary of Oregon's Mission In Tamshlyacu, Peru 1966-1973.

APPROVED BY THE MEMBERS OF THE THESIS COMMITTEE:
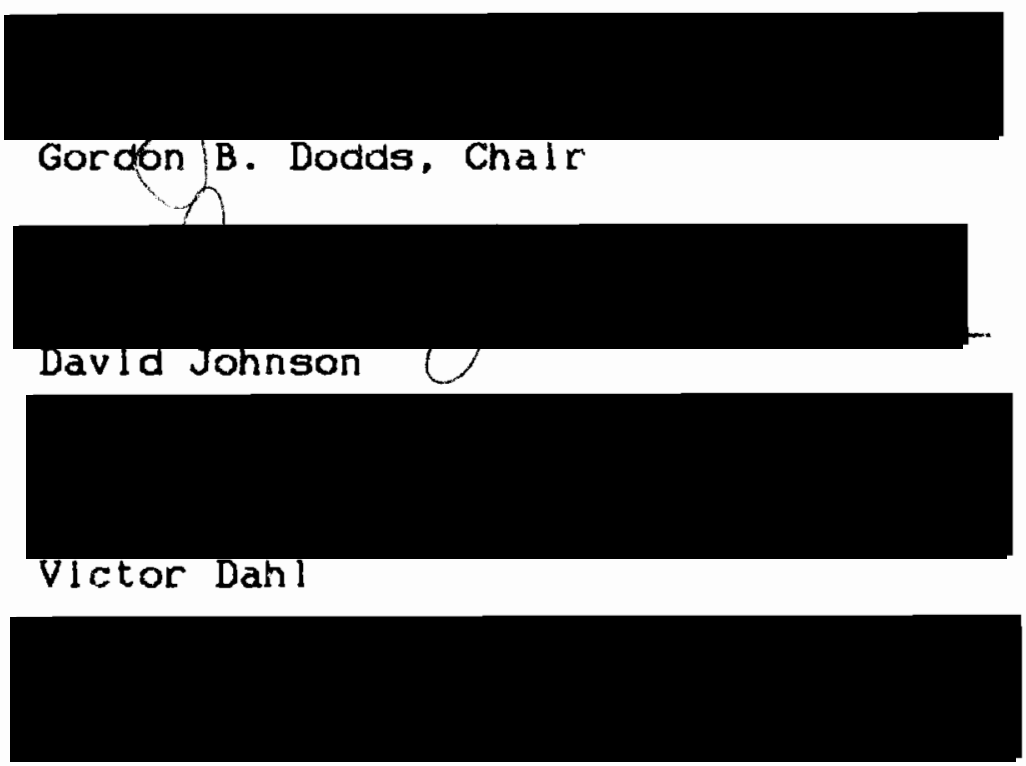

Earl Rees

On August 17, 1961, Pope John XXIII appealed to reilgious communities in the United states to send tenpeccent of their personnel to assist the Churuh in Latin Riserica. Thousands answered his cali. Tris unstecendented effort drew foll menders of the sisters of 
St. Mary of Oregon to the vlllage of Tamshiyacu in the jungles of Peru from 1966 to 1973.

The purpose of this thesis is to examine the experlence of the sisters within the context of the total misslonary effort and the religious changes affecting the Cathollc Church In the Unlted States and Latin America durling the $1960^{\prime} \mathrm{s}$.

Printed materials on the total misslonary effort are almost exclusively limlted to Gerald M. Costello's book, Mission to Latin America: The Sucesses and Fajlures of a Twentieth Century Crusade. The United States Cathollc Mission Assoclation and the Secretarlat for Latin Amerlca within the United States Conference of Catholic Bishops had no historlcal materlals available on American misslonarles. Records and information on the mission to Tamshiyacu were surprisingly limited In the Archives of the Archdiocese of Portland in Oregon. The most complete record of the mission are contained in the newspaper articles in the Catholic Sentinel and in the Archives of the Slsters of St. Mary of Oregon. Approxlmately 150 letters from the four missionarles have been preserved. Recent personal intervlews clerlfled and added detalls to the events of the missionarles: Ilves at Tamshlyacu.

In the midst of the changes In Finerlcan soclety and the "revolution" Inltiated by Vatican Council II 
(1962-1965), the papal plan fell short of 1 ts orlginal goals but the surprising successes of the plan continue to bear fruit for Catholics in both the United States and Latin America. Amerlcan Cathollics were drawn out of their parochlal vision into a larger experlence of a global church as the mlsslonarles returned with slides and stories of conditlons of people all over Latin Amerlca. Lat In Amerlcan Cathollcs developed their own experlence of church, base communltles, that was and contlnues to be, reflective of their own needs and cultures.

The story of the four slsters of St. Mary of Oregon is filled with adventure, courage, humor and self-less dedication and service. Thls thesis is an attempt to preserve their unique story for both the communlty and for the Church in the Paclfic Northwest. 
A HISTORY OF THE SISTERS OF ST. MARY OF OREGON'S MISSION IN TAMSHIYACU, PERU 1966-1973

by

SISTER PAULINE ROSE WAIBEL

A thesis submitted in partial fulfliment of the requirements for the cegree of

\author{
MASTER OF ARTS \\ in \\ HISTOR'
}

Portland State University

1990 
TO THE OFFICE OF GRADUATE STUDIES:

The members of the Committee approve the thesis of Sister Pauline Rose Walbel presented July 16, 1990.

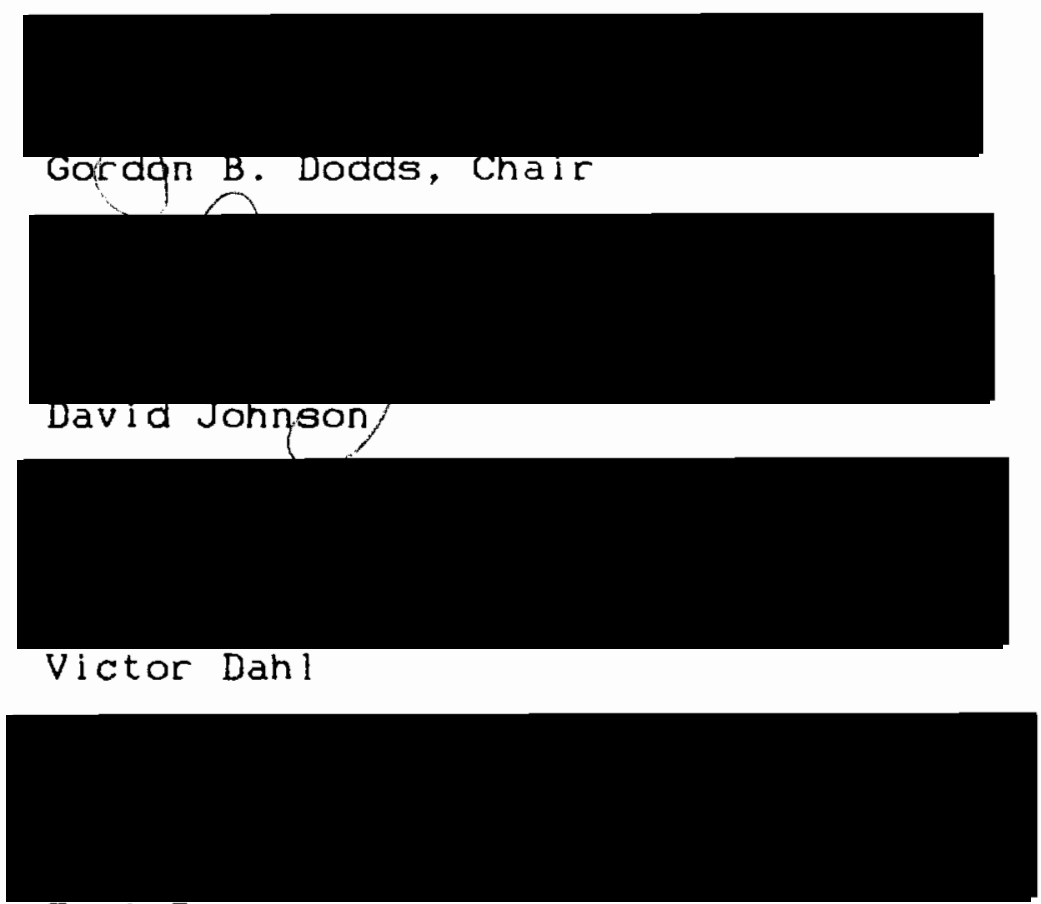

Earl Rees

APPROVED:
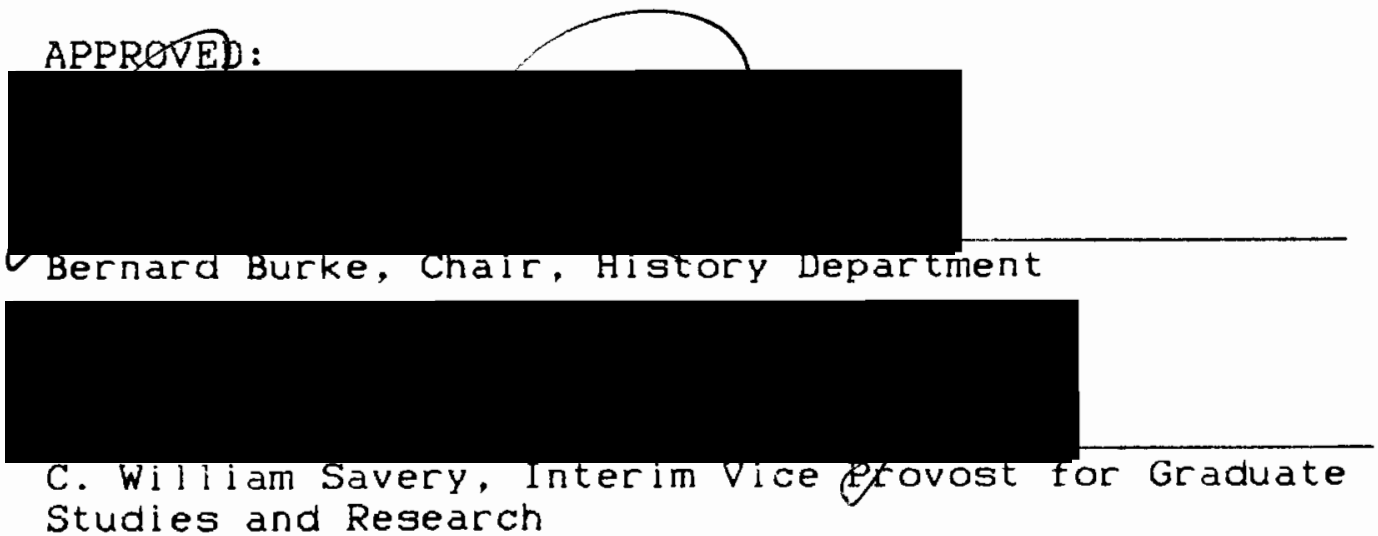
TAELE OF CONTENTS

LHAFTEF

FAGE

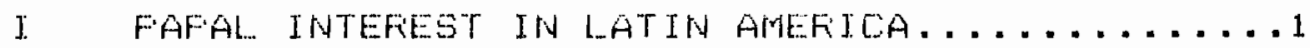

I I FOFTLEND AFCHITOLESAN INTEFEST IN LATIN AMEFICA. ..............................

II I LANGUAGE SCHOOL IN LUEFIVAVACA...............

IV AFFIVAL IN LIMA..................

$\checkmark$ THE FIRST YEAF AT THE MTSGION.............

VI THE SECONI YEAF AT THE MISSION............

VII THE THIFD VEAF AT THE MISSION............70

VIII THE FOUFTH YEAF AT THE MISSION...........80

IX THE FIFTH YEAF AT THE MISSIUN.............8\%

$X$ THE FINAL YEAF AT THE M1SSION............9\%

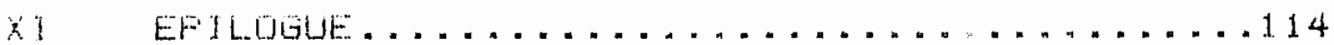

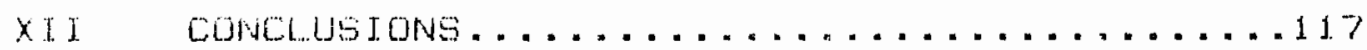

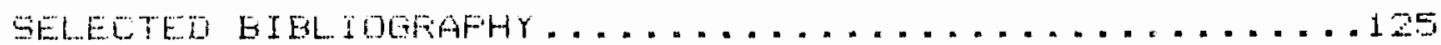




\section{CHAPTER I}

\section{PAPAL INTEREST IN LATIN AMERICA}

From its beginnings, the Roman Cathollc Church has been a missionary church reaching out to peoples of every race and nationality. Its history records the efforts of missionary communities on every continent and in every age. The missionaries and their efforts, however, were not always well received by the native peoples. In Africa and in the East, the Catholic Church is viewed as an "unwanted imposition from without inseparably assoclated with the progress of the colonlal powers". 1

Spanish colonialism brought the Catholic faith to Peru in 1531 with the armies of Pizarro. The Gospel was Introduced as an accompanlment of the Spanlsh civilization and "the peoples seem to have shown little unwillingness to receive it".2 The work of the missionaries throughout Latin America followed the same basic pattern. Priests were encouraged to learn the local

1Stephen Neill, A History of Christian Mission. (New York: Viking Penguin, Inc., (964), 250.

2 Ibid., 169. 
languages and to provlde the beginnings of a Christian literature in them. Schools were established, but higher education was Iimited to those of Spanlsh or mixed blood.3

The Spanish style of Catholicism was a highly devout, piously spiritual expression of the falth essentially llmited to the Spanlsh elite in Latln Amerlca. In Peru, the Lima Council of 1552 discussed which sacraments would be made available to the Indians. The Council decided that until the Indians were better instructed and stronger in their faith, they would not be allowed to receive communion and their sacramental life was limited to baptism, matrimony and penance.4 No serious effort was made to build up a native clergy: "It was often maintained that there was a sufficiency, indeed an excess, of priests in the New World." 5 The ranks of the clergy were limited to the Spanish until the Third Council of Lima in 1792. This council lifted the ban on ordaining mestizos. Two years later, the first Indian priests were ordained. 6

3ibid., 173.

4 Ibid. 5 Ibid., 174. Gibid., 175 . 
The "splritual conquest" of Latin Amerlca by the Spanlsh and Portuguese misslonarles in the slxteenth century was impressive in terms of the number of conversions to the Church. But the aloofness and elltism of Hispanlc Cathollclsm would haunt the Church In the twentieth century.

By 1960 , the Church in all Latin America was at a crisis point. Roger E. Vekemans, S.J., the Director of the School of Sociology of the Catholic Pontifical University of Chile, wrote that the Cathollc Church was in danger of losing Latin America because Hispanic Catholicism failed to meet the social needs of the people. Spanish Catholicism, he wrote, had been centered on the highly spiritual, almost mystic elements of the faith rather than being concerned about man's life in this world. Non-Catholic missionaries were pouring into the 'vacuum' created by the limited number of vocations to the priesthood; only 30,000 prlests were avallable to serve $180 \mathrm{mlll}$ ion Catholics." 7 Vekemans warned that:"A continent which had always been traditionally Catholic is now open to anybody and everybody and is being lost to the Church".8

7 Vincent T. Malone, "High Hopes for Peru", 21 May 1960 , America, 282-3.

8 Ibid., $282-3$. 
In 1961, a new missionary call was sounded. Whereas in earlier times European misslonarles reached out to reglons untouched by Cathollclsm, thls new effort was manned by American Catholics responding to a papal plea to go to Catholic Latin America. Thousands answered the call of Pope John XXIII. This unprecedented mlssionary effort, rooted in decades of papal interest and growth and development of the Church in both Latin America and the United States, drew four members of the Sisters of St. Mary of Oregon to the jungles of Peru from 1966-1973.

The roots of papal interest in Latin America in the twentleth century can be traced to Pope Leo XIII. Throughout his pontificate, Pope Leo was interested in the diplomatic relations of the Church with other countries. While his European diplomatic efforts were disappointing and short lived, his social teachings outlined a role for the Church in the modern industrial world. In 1899, Pope Leo convoked the first general meeting of the Latin American hierarchy in Rome. The meeting emphasized the regional and international dimension of the Church and gave the bishops personal contact with the pope whose social teachings were the seeds for change in the future

7 Vincent T. Malone, "High Hopes for Peru", 21 May 1960, America, 282-3.

8Ibid., 282-3. 
of the Church in Latin America.9 Specific papal actions aimed at Latin America began in earnest during the 1950 s.

Pope Pius XII was disturbed by the imbalance between the numbers of priests and people In Latin America and the failure of the Church to be an effective force with the masses. Other concerns included the presence of Protestant misslonarles in Latin Amerlca and the threat of communism.10 Pius' concern inspired both personal, direct action and the establishment of structures for long-term assistance to the continent by the United States, Latin America and the Vatican.

American activity during the early $1950^{\prime}$ 's centered around two individuals, Rev. Frank Kennard of the Archdiocese of Portland in Oregon and Archbishop Richard Cushing of Boston, and the formation of the society of St. James. The details concerning the foundation and the direction of the Society vary according to the memories of these two men. Kennard's interest in Latin America began in 1953 when he read about Pope Pius XI's concern for Latin America. He was asked to wait a year by Archbishop Edward Howard. "I wrote to various places in Latin

9Gerald M. Costello. Mission to Latin America: The Successes and Failures of a Twentieth Century Crusade. (Maryknoll, New York: Orbis Books. 1979), 26. 10 Ibid. 33. 
America to see if they were interested," he sald In 1977. "and the first one who answered was Archbishop Landazur 1, the future cardinal who was coadjutor of Lima at the time. He sald they'd be glad to have me, and that's how I ended up In Peru". 11 Rev. Frank Kennard arrived in Peru in September 1954 as possibly the first American diocesan priest-missioner to volunteer for Latin America.12

Archbishop Francesco Lardone, the apostolic nuncio, requested Kennard to write to several American bishops asking them to send more priests to work in Peru. Cushing invited him to Boston in 1958 to give a presentation to the priests on the needs of the Church in Peru. Several priests expressed interest; Kennard extended his stay in Boston to help write the rules of the society of St. James. The Soclety was founded on July 25, 1958, and was legally incorporated in accordance with the laws of the Commonwealth of Massachusetts on December 31, 1958. Its object was to recruit and train diocesan priests who, with the approval of their bishops, would volunteer to give five years of service in Latin America. According to a pamphlet published by the Daughters of St. Paul circa

11 Ibid., 36.

12 Ibid. , 35. 
1962, the Society had much earlier roots under the direction of Archbishop Cushing:

In 1948, on my first visit to Rome as Archbishop of Boston, I informed His Hol iness, Pope Plus XII, of a "Lend Lease Program" which I had originated for priests. It was a plan to send volunteer priests to missionary dioceses to ease the critical need for spiritual assistance in those areas. The Holy Father was greatly interested in the program, to the extent that he suggested the possibility of assisting the Catholics in Latin America, where there was a great lack of priests.13

Cushing made no mention of Kennard's vlsit:

On the occasion of the one hundred and fiftieth anniversary of the diocese of Boston I followed the suggestion of the Holy Father and founded on the Feast of St. James, July 25, 1958, The Missionary Society of St. James the Apostle." 14

According to Kennard, he and Cushing had a "parting of the ways" because each man had a different vision of the society. Cushing believed in a heavy political emphasis within mission duty: the missioners were to save Latin America from communism. Cushing made sure that volunteers received copies of J. Edgar Hoover's Masters of Deceit and his own Questions and Answers to Communism. 15 Kennard simply wanted the Society to help

$13_{R}$ i chard Cardinal Cushing, The Missionary Society of St. James for Latin America. (Daughters of St. Paul. $1962), 2$. ${ }^{14}$ Itid. , 3.

15Costello, Mission to Latin America, 38. 
In the poorest parlshes of Latin America.16

By 1962, the Soclety had grown to 99 member priests, 39 from Boston and 60 from other dloceses. Members represented 26 states as well as England. Ireland, Scotland. Wales, Canada, Australlan and the Phlllpplne Isl ands. 17

Latin American endeavor was based upon the formation of the first regional conference of bishops. During July and August of 1955, bishops from Mexico to Argentlina met in Bogota, Colombia to create CELAM, Consejo Episcopal Latinoamericano, a loose, regional federation designed to assist the bishops in operational coordination. Seventeen national Latin American conferences plus a sectional conference representing the hlerarchles of the five Central American countries were organized into one cohesive unit.18

Roman efforts derived from the creation of The Pontifical Commission for Latin America, CAL, In 1958. This commission was charged with channelling world-wide

16 Francis Kennard, personal interview, 5 May 1990.

17 Cushing, "The Missionary Society of St. James for Latin America", 5 .

18Costel10. Mission to Latin America, 34. 
efforts into Latin America. The Commission was entrusted with the duty:
to study in 1 ts entirety the fundamental
problems of Catholic life in Latin America, encouraging close cooperation among the Roman congregatlons responsible for their solution. It should also follow and sustain CELAM and its general secretariat.19

Several countries offered assistance to the Commission: Spain, Italy, France, Belgium, Ireland, England, Portugal, Germany, Austria, Switzerland and Holl and (sic).20

At the time of his death in 1958, two of the most important commissions for the future of the Church in Latin America had been established by Pius XII, CAL and CELAM. His successor, John XXIII, would use the structures established by Pius XII and his own methods to bring direct assistance to Latin America.

John XXIII had been personally interested in the region for some time. When he was named archbishop and apostolic visitor to Bulgaria in 1925, he had been told he would be there only a short time before being appointed nuncio to an unidentified South American country.21 In the same year, he had helped plan a papal missionary

19 Ibid., 41.

20 John J. Considine, "The Papal Program for Latin America". American Ecclesiastical Review. March $1966,155$.

21 Costello, Mission to Latin America, 48. 
art exhibit. The transfer to Latin Amerlca never came, however, and he had to wait until his election as pope to act on hls interests in the reglon. One of hls flrst offlclal acts as pope was to welcome the Latin Amerlcan bishops who were in Rome and to express his special concern for their problems. 22

Under his direction, the Pontiflcal Commission sponsored an inter-American episcopal conference in November 1959 at Georgetown University in Washington D. C.. At the close of the conference, the representat Ives from Canada, Latin America and the Unlted States Issued a joint statement:

We were all profoundly impressed by the apostolic endeavors and the many consoling results already realized against tremendous odds by the Hierarchy of Latin America.

We were in full agreement that we should urge the general assemblies of the Bishops of our respective countries that the Church in the United States and Canada should be fully informed about these problems and should give every possible assistance through prayer, the media of information and through whatever ald is within our power now and in the future, and especially by personnel and financial support.23

The American bishops wasted little time in responding. The Latin American Bureau was created as a unit of the

22 Ibid.

23Considine, "The Papal Program for Latin America", 156. 
National Catholic Welfare Conference on May 3, 1960. The Bureau had five goals: to maintaln a llalson with CAL and CELAM; to operate an orderly program of aid under the authority of the bishops of the Unlted States; to asslst the U. S. religlous communlties in the provision of personnel to Latin America; to transmlt requests for personnel and material ald as recelved from the bishops of Latin America; and to provide information on the Church's needs in Latin America to the Catholic millions of the United States, in particular to the bishops, priests, brothers, sisters and lay leaders.24 Within six months, the Latin American Bureau gave support to the establishment of the Center for Intercultural Formation in Cuernavaca, Mexico. The first class of American misslonaries arrived in June 1961 and studied under the watchful eye of Monsignor Ivan Illich, the director of the Center.

Latin America was a topic of interest in the American magazines in 1960. It is difficult to ascertain the impact of the reports in contemporary American magazines had on John XXIII's interest in Latin America. It is highly unlikely that he would have ignored the reports.

24 Ibid., 157. 
In January 1960, Ave Marla magazine published an interview with Roger E. Vekemans, a Belgian Jesuit, who was the Director of the School of Sociology of the Catholic Pontifical University of Chile. In his opinion, Lat in America was now open to anybody and everybody and being lost to the Church.25 He argued that a "highly devout, piously spiritual Catholicism "did not provide a life the people could be satisfied with in the face of modern advances. The people were vulnerable to communism because it presented itself as the only solution to all the misery of the continent. He saw a correlation between the inner weakness of Hispanic Catholicism and the threat of communism, but he also realized that "even if communism or Protestantism or spiritism did not exist, still we would have a real problem in Latin America."26 His prediction for the future was grim:

Give me forty more years and you can say that if the Church loses Lat in America, she loses one-half of her world-wide population and that could be a crisis within the Church even more serious than the oriental Schism or the Protestant Reformation. The problem is that serious. 27

25 Roger E. Vekemans, "Is the Church Losing Latin America?" Ave Maria, 9 January 1960, 5.

26 Ibid., 6 .

27 Ibid., 10 . 
He concluded the interview with four areas of need: 1) "We have to awaken an interest in the Catholics of the world towards their brothers in the Falth who are in serious danger of being lost in a wave of new Influences"; 2) Latin America can not save itself with only its own resources, it needs help; 3) There is a need for 200,000 more priests. Plans must be made carefully to know where to begin--schools, parishes, to the elite or to the masses; 4) "When we $f$ ind the answers, we are merely beginning to stem the flood of Catholics who are falling away. Courage, resources and prayer are the weapons we have to use. The great struggle is actually beginning. By 1990 the stakes will be $360 \mathrm{milll}$ on people." 28

Vekemans' article was quoted in Newsweek later in the month. The Newsweek article was more strident in its evaluation of the situation. The Church was losing its grip on Latin America and "nobody knows it...nobody cares."29 At least eighty-six percent of the people were nominally Catholic but the Church was not meet Ing the needs of its members. The vacuum was being filled by

28 Ibid. 5. 80.

29"A Mission Territory", Newsweek, 18 January 1960 , 
secularism, communlsm, natlve rellglons, Freemasonry and 6,000 Protestant mlssionarles, 30

Across the ocean, in March 1960, John XXIII introduced possibly for the first time the notion of Catholics around the world assisting the Church in Latin America. While speaking to the Superior Generals of both men and women's religious orders, he sald that:

The future of the Church in the vast territories of Latin America appears $r i c h$ in ineffable promise: and We nourish the firm conviction that Catholic spirit and life in those regions have in themselves sufficient strength to encourage the most optimistic hopes for the future. Those treasures of spiritual wealth so profusely bestowed there in the past, and yet more those which will be given with full hands in the future, will surely give rise to rich fruits of holiness and grace, to the greater joy of the Church of God. It is necessary that all those who wish to share in the apostolic anxiety of Our heart, would make every effort and every sacrifice to meet the expectations of that great continent, Latin America.31

Shortly after, in the United States, an article appearing in America magazine was more hopeful of the changes taking place in Latin America. The reality was that the Church continued to be identified with the weal thy class:

The high fees sometimes asked for Masses and for the administration of the sacraments, as well as the clergy's frequent support of the affluent

30 Ibid.

${ }^{31}$ Costello, Mission to Latin America, 51. 
landowners, seemed to Just Ify the people's suspicions. 32

But hopeful signs were emerglng. The seeds of the social teachings of the Church first sown by Pope Leo XIII were taking root: "The Indian is becoming conscious that the Church not only talks social justice but leads the way to it."33 The people were learning more and more about their faith and more about their rights as children of God.

By the end of 1960 , means were now available to the Church in the United States, Latin America and Rome to respond directly to the needs of Latin America. Interest was high and the stage was set for an unprecedented announcement.

On August 17, 1961, Pope John XXIII, through Monsignor Agostino Casaroli, made an appeal to the North American superiors who were meeting at the University of Notre Dame. The presentation was divided into three main areas: Objective Facts, Present Catholic Situation and Future Plans.

The first section gave a clear picture of the importance of Latin America to the Church. Latin American

32Vincent T Mallon, "High Hopes for Peru" America, 21 May 1960, 282.

33 Ibid., 283. 
Catholics represented about one-third of world

Catholicism. A dangerous situation existed because of the lack of clergy and the "Inroads of Protestant sects, the secularization of the whole way of life, Marxism, the influence of which is felt in the universities and is very active, even dominant, in almost all labor organizations; and finally a disquieting practice of spiritism".34 It ended with the conclusion that the Church had two duties: first, the hierarchy must collaborate so "that not even a small part of that precious heritage of the Catholic religion which is Latin America would be lost." Secondly, the Church has:

the sacred duty of aiding those apostolle forces, mostly still latent in Latin-American Catholicism, to activate themselves, so that their strong support may be rellied upon to engage with high hopes of success in the great adventure of the conquest of the world to the truth of the faith and to the beauties of Christian living. 35

Section II entitled "Present Catholic Action" compared the insufficient means avallable to the Church in Latin America with the resources of Catholics in North America. The lack of personnel was so great that the tasks would "seem impossible, or at least extremely difficult for Latin American Catholicism to be able,

${ }^{34}$ Costello, Mission to Latin America, 275. 35 Ibid. , 276. 
unalded, to overcome this critical situation in time." American Catholics were encouraged to respond "heartily" to the pressing appeal for Lat in Amerlca whlch the Holy See considered essential for the general interest of the Church. The Holy See acknowledged the reality that there were not enough priests and religious to meet the needs of Amerlcan Cathollcs "but it is also true that in comparison you are much more numerous in proportion to total Catholic population than your confreres in Latin America". 36 Section III, "Future Plans" announced the Ten Year Plan proposed by Archbishop Antonio Samore of the Pontifical Commission. The plan called for American religious communities to send the ten-percent of their best and most qualified vocations to fulfill the needs of the Church in Latin America.

If an extraordinary generous and wise effort is made within those ten years, we have every reason to expect that, with God's help, the battle will be won." 37

The Plan caught the imagination and the enthusiasm of American Catholics, both lay and religious. The Church in the United States was beginning to emerge from the "ghetto mentallty" of the 1950's and was basking in the electlon of the first Catholic president, John F. Kennedy. The

36 Ibid., 277-8.

37 Ibid., 279. 
financial and personnel resources were avallable to contrlbute to the papal cause. By January 1965, 4,091 bishops, priests, sisters, brothers and laity were working in Latin America.38 The Sisters of St. Mary of Oregon joined the effort in 1966 by assisting Father Frank Kennard at the little village of Tamshlyacu, Peru.

38 Considine, "The Papal Program for Latin America", 161. 


\section{CHAPTER II}

\section{PORTLAND ARCHDIOCESAN INTEREST IN LATIN AMERICA}

The Sisters of St. Mary of Oregon were invited by Kennard to join his efforts in the little village of Tamshiyacu, his third mission in Peru. He brought a wealth of experlence to the village in 1960. He had spent hls first five years in Peru in the village of Huarochiri. He continued his efforts in Abancay in the state of Apurimac in 1960. Members of what would become "The Shining Path" were already organizing in the mountains. Kennard described the group as "Peruvlan ethnologists" who sympathized with the terrible lot of the Indians. Communism seemed to be the only solution because the Church had not moved far enough; it was still assoclated with the conservative right. 39 Father John Morris, a priest from the Milwaukee, Wisconsin, diocese, joined Kennard's mission in 1960. With monies given to them by the people of their dioceses, the two priests purchased a 1990.

${ }^{39} \mathrm{Fr}$. Francis Kennard, personal interview, 2 May 
dwelling large enough to house the additlonal prlests expected from the Society of St. James. The arrlval of American prlests proved to be a disappointment. The new recruits were told to Ignore Kennard because of the earlier disagreement he had with Cushing over the direction of the Society. Within a short time, Kennard and Morris decided to sell the house and leave for $\operatorname{Lima}, 40$

While in Lima, the Vicar Apostolic of Indiana, Damascus La Berge, approached Kennard with the possibility of working in the Vicariate of San Jose del Amazones. The Vicariate contained 60,000 square mlles and $150 \mathrm{miss}$ lons. Tamshiyacu, the largest village, had a populatlon of 3,000 people and was the home base to the $40 \mathrm{missions}$ on the Amazon and the tributary rivers hundreds of miles away.41 Kennard accepted the position and shortly thereafter, the Archdiocese of Portland established a formal relationship with the Vicariate. Portland agreed "to provide personnel and funds for this Mission to the

40 Francis Kennard, personal interview 2 May 1990.

41 Gorman Hogan, "Tamshiyacu: An Inspirational Treat', "Catholic Sentinel [Oregon] 4 February 1966 $\sec . A: 14$ 
extent of its possibilities". 42 The people of the Archdlocese were kept informed of the developments of the misslon through articles in both the secular and rellglous press.

In 1963, during a visit to Oregon, Kennard was Intervlewed by the oregon Journal. He was outspoken in his criticlsm of American economic Interests in Latin America. Many Americans criticized the Peruvian oligarchy for the current social injustice: almost ninety-five percent of the people are very poor and flve percent are very weal thy.

But Amerlcans forget that the lion's share of industry is owned by American and European interests. Peruvians who work in the American owned mines earn 83 cents per day. In jungle areas, like the area I live in, folks work 20 to 25 days a month to raise enough to eat, The last few days, they work 10 or 12 hours a day to make about $\$ 1$ a day raising rubber or jute, their money crops for consumption in the United States. 43

Other money crops, such as sugar, were limited by American quotas. Prices for Peruvian goods dropped while prices for American and European commodities increased in 1962.

42Archbishop Edward Howard, Letter to Damascus La Berge, n.d., Sisters of St. Mary of Oregon Archives, Beaverton, Oregon. Subsequent references will be abbreviated as SSMO.

43"Yanks Worsen Lat in woes, Warns Priest" Oregon Journal [Oregon], 23 February 1963, sec. B:2. 
The economic situation was serious; the country was ready for drastic change:

Revolution is imminent. Whether it comes peacefully, by democratlc means, whlch support free enterprise, or through bloody totalitarianism depends malnly on our efforts to solve the sltuation in a falr way. 44

The staff of the mlssion increased in number. The Archdiocese sent a second priest, Father James Kalberer, to Tamshiyacu in October 1965. The mission was staffed by the two Portland priests, three lay volunteers from Canada and a Peruvian, Leonides 0lulo. Leonides was a deaf-mute from the mountains who had been wlth Kennard since his arrlval in Peru. Interest in the mission was growing among the Oregon Cathol ic community. The Archdiocesan newspaper, The Catholic Sentinel, carried a series of articles on the mission during the month of February 1966. The managing editor of the newspaper, Gorman Hogan, and his wife traveled to the mission with their daughter who was entering the Peace Corps.45 The first of the articles is a vivid description of the difficulty of reaching the mission some 7,000 miles distance

44 I bi d.

45Gorman Hogan, "Tamshiyacu: 'An Inspirational Treat", "Catholic Sentinel [Oregon] 4 February 1966, sec. A: 14-15. 
from Portland. The second descrlbes the efforts made to combat two of the worst enemles of the mission: disease and ignorance.

The mlssion dispensary treated between 50 and 100 patlents each day. The most common allments were dlarrhea, worms, anemla and snake bltes. The people were undernourished, eatling only 1100 calories per day--oniy one-half baslc daily requlrements.

Medicines were in short supply and It was difflcult to get the medical donations from Canada and the United States into the country.

Education in the jungle was limited because of the difficulty in obtaining qualifled teachers in the poor districts. It was a situation of "no teachers and no schools" throughout much of the country.46 Religious men and women did teach in the public schools of Peru for a small salary paid by the government and were able to teach religion classes. At the mission in Tamshlyacu,

Pay is low, books, pencils and paper are scarce. often the only book availabie is the one used by the teacher. 4 ?

46 Ibid., 14

47 Ibid. 
A coupon for further information on joinling in the support of the mission was included in the article. The article concludes with a reflection on the gratltude of the people in the jungle for the education, medical attention and understanding given to them, in part, by the people of the Archdiocese in Portland. The third article announced the bullding of a Clvic Center for the village made possible by the donations of the Sentinel readers. The plan was to eventually transform the Center into a high school that would be one of the few high schools in the area. Since qualified teachers were rare in the area, the long-range plans included the "possibll1ty that the school at Tamshiyacu ultimately will be staffed by Sisters from Oregon." 48 No specific community was named in the article. But Kennard had had a specific community in mind for several years.

Kennard had first approached the Sisters of St. Mary of Oregon about helping in Peru in the winter of 1958 when he was home for a visit. The superior general at the time, Mother Colette, was interested in the prospect of a foreign mission but felt that this was a project for the

48 Gorman Hogan, "Combined Civic Center and High School to Open soon at Tamshiyacu in Peru; gifts Aid Building," Catholic Sentinel [Oregon] 18 February 1966 sec. A : $14-15$. 
future.49 In the Chapter (a meeting of elected delegates from within the communlty whlch occurred every $s \mid x$ years) of 1960, the community passed a proposal to investigate the possibility of a mlssion. Because of a varlety of other commitments and concerns, Mother Angela, who succeeded Mother Colette as Superlor General, dld not immediately act on the proposal. She did, however, feel that some action needed to be taken during her administration. Another factor was an unwritten understanding among the community that the membership needed to reach 225 before it could venture into the foreign mission fields. Peru was one of two options open to the Community. Father Kinch, the brother of one of the sisters, was working in Africa at the time and had asked the sisters for help. Mother Angela opted for Peru because Kennard was more visible to the community and the mission was supported by the Archdiocese. 50 In the fall of 1965, Mother Angela sent a letter to the members asking those who were interested in volunteering for Peru to submit a letter of intent explaining why the sister wanted to go. In late January 1966. Mother Angela and Sister M. Roberta went to

${ }^{49}$ Francis Kennard, personal interview, 2 May 1990. 50 Sister Angela Lehman, personal interview, 10 March 1990. 
Investlgate the situation flrst hand. Mother Angela was not personally exclted about the prospect of a mlssion. She felt she "had to go" whlle Slster Roberta was "bltten by the mission bug". Mexico City was the flrst stop on their Journey to Peru. Because of 11 lness, Father Kennard could not join them for a few days. The sisters managed to see some of the sights of the city without speaking a word of Spanlsh. After Father jolned them, they visited the international training center for Latin Amerlcan Mission Volunteers in Cuernavaca, Mexico, a city flfty miles south of Mexico City and then proceeded on to Tamshlyacu. The sisters spent ten days examining the details and operation of the mission, especially its educational needs and the possibility of the Sisters of St. Mary of Oregon going there to supervise the program.51 Upon their return, Mother Angela and Sister M. Roberta recommended that the community accept the mission; the Council agreed. In March, the Community announced to the Archdiocese its intent to send sisters to Peru. The sister volunteers would teach religion in the public school, seek to upgrade the entire level of general education, supervise and teach in the new hlgh school and

5 Ibia. 
coordlnate the C.C.D., Confraternity of Chrlstlan Doctrine (rellglous education program), both in teaching and in the educating of teachers.52 Four sisters would be selected for the first foreign mission of the communlty.

Over thirty members of the community volunteered to go. The Council (slx slsters who are elected to advise the Superior General) made recommendations for the selection but the final decision was up to Mother Angela. The mission was on everyone's minds as the weeks wore on. Finally on Mother's Day, Mother Angela called the three who were selected: Sister Kateri Petite, Sister Elizabeth Nosack and Sister Margaret Mary Coussens. The three slsters had to contain their excitement untll the news was officially announced to the community. The final place on the list was "TBA", "to be announced".

Sister Katerl was the youngest of the group at age 29. She was from Grande Ronde and had entered the community in 1952. She was attracted to the ldea of becoming a missionary but had accepted the reality that the possibility was remote. Occasionally there was talk in the communlty of a mission in Alaska which interested Sister Kateri. She was content to be teaching in parlsh

52 "Sisters of St. Mary of Oregon Will Send Nuns to Peru Mission," Catholic Sentinel [Oregon] 14 March 1966 sec. A: 1 . 
schools in Oregon until the announcement was made concerning Feru; she had her letter in the next day.s3

Sister Elizabeth's dreams drew her beyond the farming community of Gervajs; she always wanted to be a missionary. While in high school, she wrote to the Maryl:noll Sisters asting for information. She was distracted from the Marytonolis by the interest and encouragement of Sister Marguerite who was teaching in the parish school. Sister Marguerite directed her to St. Mary of the Valley boarding school to finish her education. She entered the community in 1944. Mother Genevieve assured her that a mission would open in Alasta when the membership reached 225 . Sister Elizabeth was number 214. The Alastian misgion never materialized. When news came about Feru, Sigter Ei izabeth was the first to get her letter into the volunteer box. 54

Sister Margaret. Mary grew up on a dairy farm near Hilisboro. While in high school, she read about Africa. Her interesst. was sparlied by the fact that one of her aunts was a missionary in the Congo. When she entered the community in 1946, she had three dreams: to travel to 1990

GSigter fateri. Fetite, personai interview, 20 May

$445 i s t e r$ Ina Marie Nosack, personal interview, Apri1, 1990. (Sister Elizabeth changed her name to Sister Ina Marie j.r 1973.) 
Europe, to be a missionary and to work among the poor. At the age of 48 , two of her dreams became reallty.55

The last place on the list remalned "TBA" for another month. Some members of the communlty jokingly Interpreted the letters to be "To Be Angela". Mother Angela had entered in 1925 and taught at various schools for thirty years prior to her appointment as motherhouse superior and her election as Superior General in 1960. She had no secret desire to be a missionary. It was the trip she had made earlier in the year that captivated her. After seeing the situation in Peru, she knew that was where she belonged. After a new Superlor General, Mother $M$. Consilia, was elected on June 13, Mother Angela, at the age of 58 , asked to go to Peru. 56

The Community announced the appolntment of the sisters in June. The plan was for them to leave in early August for the language school in Cuernavaca, Mexico. After completing four months of study, they would go to the jungles of Peru in late December. Some women in St. John's Parish in Milwaukie, Oregon, sponsored a silver tea to honor the sisters who were the flrst mlssionarles of the Sisters of St. Mary of Oregon: 1990.

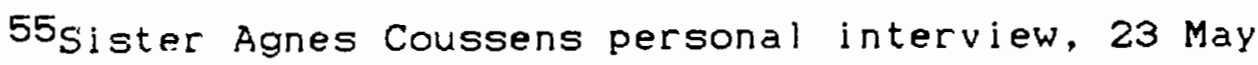
56 Sister Angela, personal interview, 10 March, 1990. 
A large group of people attended to meet the missionarles and to vlew a display of articles, including handwoven rugs, scarfs, dolls, a mission cross and plctures of Father Kennard's mission, whlch were brought from Peru by Mother Mary Angela and Sister Mary Roberta, who visited the mission in February. 57

Sisters Margaret Mary and Elizabeth Nosack were working in Washlngton County at the tIme of the announcement. Slster Margaret Mary was the fourth grade teacher at St. Matthew's School in Hillsboro. Sister El izabeth Nosack was the principal at St. Cecllia's School in Beaverton. Both of them were excited about the new assignment:

The sisters expressed interest in their new assignment with all its challenges and appear to be undaunted by the thought of the primitive conditions under which they will be living while in this mission field.58

The summer of 1966 was a flurry of activity for the sisters. Sister Kateri spent many hours making reel to reel tapes of music and getting her passport, shots and physical. Mother Angela spent some time in Seattle talkIng with Sister Theophane, a Providence slster who had worked in the language school in Cuernavaca. Sister Margaret Mary spent $f$ ive weeks completing a reading

57"Three Sisters Appointed to Work at Archdiocesan Mission in Peru," Catholic Sentinel [Oregon] 6 June 1966 , sec. A: 21 .

58"Sisters From County Schools Assigned to Peruvian Mission," Hillsboro Argus, [Oregon] 9 June 1966, sec. A: 2 . 
program in Bozeman, Montana, and had to rush home to get her things in order. Sister Ellzabeth practiced firing a gun that her brother had glven her. The question of what to wear in the jungle was discussed in the General Chapter durlng June. Rellglous communltles In the Unlted States were in the beginning stages of modifying their hablts for the contemporary world. The misslonarles would be the first members of the Sisters of St. Mary of Oregon to change out of the long, full length black habit. It was decided that:

a committee be appointed to design the habit of the missionaries in Peru and that the hablt be worn as an experimentation. 59

The sisters modeled the habit at the Departure Ceremony later in the summer:

The garb is a two-piece dress of serano fabric. The top part is an over-blouse with a soft white rolled collar. The skirt is simple, with two box pleats, and reaches to mid-calf. Off the forehead is worn a gray veil with a stand-up corona $f$ inished with a whlte band matching the collar. Worn around the neck is a silver chain from which hangs the Saint Francis Xavier Mission Medal of the Sisters of St. Mary of Oregon.

The new garb, worn only by the Misslon Sisters, is contemporary, practical and distinctively religious in design, Mother M. Consilia said.60

${ }^{59}$ General Chapter Minutes 1966, SSMO Archives.

60 "Oregon Sisters Prepare to Leave for Archdiocesan Mission in Peru," Catholic Sentinel [Oregon] 5 August 1966, sec. A: 25 . 
Invitatlons were sent out to the frlende and relatlves of the community to celebrate the Departure Ceremony on July 31, 1966 at the Motherhouse at St. Mary of the Valley. The ceremony Included:

a procession, a 'prayer for the travellers', presentation of asslgnment cards (cards listing the assignment of the sister for the next year) by Mother Mary Consilia, mother general of the Slsters of St. Mary of Oregon; blessing of mission cruclfixes, renewal of vows by the missionaries, a departure hymn, Benediction and a Recessional.61

During the address, Father Joseph Neuville reminded the community that it too was participating in a "great adventure" with the missionaries who were going to Peru. The sacrifices and challenges that were ahead belonged "to the Community as a whole, those going and those staylng beh ind" . 62

A reception was held on the east lawn after the ceremony. The decoration reflected a Peruvian theme:

Boxed flowers and paper sculptures encircled and dotted the lawn. The Lat in American decor continued through table decorations and entertainment. 63

61 Ibid., p. 25

62 Fr. Joseph Neuville, "Departure Day" 31 July 1966. SSMO Archives.

63"Oregon Sisters Prepare to Leave for Archdiocesan Mission in Peru," Catholic Sentinel [Oregon]

5 August 1966 , sec. A: 25. 
The departure day was qulckly approachlng but the community was not yet finished with its send-off of the missionarles. Two of the slsters wrote and directed a play entitled "My Fair Missionary". It was presented on August 14 as a trlbute to the mlsslonarles at Mlrlam Hall at St. Mary of the Valley and was open to the public. The following descrlption of the play was Included with the listlng of the cast:

This play takes place in a village of Peru,
South America, remarkably near the village in
which the Sisters of St. Mary will be working.
(Any resemblance to persons, places, or to
things is purely coincidental.) Here we find
four missionaries beginning thelr work. The
Local Prefect is not convinced the Sisters will
succeed. This is the story about how they
proved to him they could succeed despite all
difficulties.64
Finally the day arrived. On August 18 , Sisters
aret Mary, Kateri and Elizabeth joined Mother Mary
la in the last farewell from the community. They
lled by car to Canada to begin their journey to
navaca.

${ }^{64}$ The program for "My Fair Missionary", SSMO Archives. 


\section{CHAPTER II I}

\section{LANGUAGE SCHOOL IN CUERNAVACA}

After an emotlonal farewell, the misslonarles left the Motherhouse early on the mornlng of August 18 and drove to Vancouver, B.C., in two cars. Sister Kateri rode with her parents and the others drove a rented car. Mother Angela had met a representative of Canadian Pacific Airllnes during her earlier trlp to Mexlco Clty in January. The gentleman told her that the airline did not charge misslonarles for thelr extra luggage. No Amerlcan airline offered such service. The sisters took advantage of his generous offer; they had 552 pounds of luggage! The alrline officials were generous and helpful in other ways. When the plane was delayed for several hours, they offered assistance in finding a motel and notifying Father Ambrose Zenner, a Benedictine from Mount Angel Abbey in Oregon who was working in Cuernavaca, of the delay.65 The sisters arrived in Mexico City at midnight on August 19 and were welcomed by Father Ambrose.

Midnight is not exactly the time to be greeted by friends in a strange city. But we were! Father Ambrose Zenner, two seminarians and $\mathrm{Fr}$.

65 Sister Angela, personal interview, 20 May 1990. 
Louls came in a large truck to take our luggage. We went with Fr. Ambrose in his car and he showed us slghts as we traveled through Mexico City at midnight. 66

After the quick tour, Father took them to Cuernavaca. Because of the late hour, no one was walting for the sisters. One of the seminarians climbed over the wall to get someone to let them into the complex. The next day, the sisters moved to the area called "Los Viklngos" only four blocks from the language school.

Durling the first week in Cuernavaca, Sister Theophane, the Providence sister from Seattle whom Mother Angela had conferred with earlier, took them on a tour of the "beautiful clty of Cuernavaca":

The flowers bloom there all year round and the climate is so summer-like all the time. The houses have walls around them in typical Spanish style. These walls are often covered with a beautiful climbing flower called Bougainvillea in reds, oranges, lavenders or yellows. Another flower that grows wlld and very tall is the poinsettia, called the Christmas Night flower in Mexico It grows on large trees and bushes and is a sight that is breath-taking. 67

They enjoyed the few days of rest before they began their studies at "the famous school of Mons. Illich".68

665ister Elizabeth Nosack, Diary, ms., 20 August 1966, SSMO Archives.

67 Ibid., 12 August 1966.

68 Ibid. 
The Center of Intercultural Documentation program was established in 1961. The program was designed to prepare missionarles from North Amerlcan in the languages and cultures of Lat 1 Amerlca. Monslgnor Ivan Ill lch, the director of the program, earned the reputation of being unorthodox in his approach to preparing misslonarles for the reallties they would face. Illlach was convinced that too many American missionaries went to Lat In Amerlca with "prejudicial attitudes and a sense of superlority".69 His "shock treatment" style challenged the motives and mettle of the students. The attrition rate was high; only thirty nlne of the first class of slxty-elght survlved the demanding schedule. 70 He had not modified his style when the sisters arrived in 1966. From the first day of class, the sisters realized that they needed to "learn fast just to survive". 71

We are 81 in the group- 53 are French speaking and the rest speak English. There are 13 American sisters and 12 Amer. priests. For the most part- they speak Spanish and we wonder what they are saying. They did use our language for the sermon. All our meals are together and we are forbidden to speak English-even if we are

69Costello, Mission to Lat in America: The Successes and Failures of a Twentleth Century Crusade, CMaryknoll, New York: Orbis Books, 1979), 107.

70 Ibid., 107.

71Sister Elizabeth, Diary, ms., 23 August 1966, SSMO Archives. 
together! Only when we go home at night do we speak English again-and then we must study.72

The sisters began each day with Mass. They then

walked to the center to begin the intensive study program:

Each of us has a different schedule. No one studies with anyone we know. We have 5 hrs. a day of classes, assignments to study and conversation to have memorized dally. In the evenings we have talks most of the nights to prepare us for our work with S. Americans. Many of the talks are to explain the culture and social aspects of these people. Social concerns and Justice are stressed. These talks are for the most part in Spanish so all in all-we are immersed in Spanish for some 8 to 10 hrs. daily.73

The talks or briefings took place twice a day.

These briefings are from people who have lived or worked in Latin American and are meant to bring us up to date on conditions here. We have had some outstanding speakers--and others that really make you stop and think. We can't believe everything- but I don't think they want us to. Discussions are really stimulated by the speakers and various other members of the course. 74

Even food was used as a means of preparing the missionaries for their future posts:

We eat more poorly than the average Mexican family but it is to prepare us for our mission. Probably the worst thing was seeing how the food was prepared. It came to us in the trunk of a

72 Ibid.

73 Ibid

74 Sister Elizabeth to Sisters, Friends and Family, 10 September 1966, SSMO Archives. 
car as it was prepared someplace else. One night we had goat meat and all got sick just at the sight.

The vegetables and frults would not be washed clean and so each of us got "Montezuma's Revenge" after the first week. We try not to figure out what $k$ ind of meat we are served. It always looks so different and is fixed with lots of herbs and mixed with rice or vegetables. There is a female dog that is a stray and the priests always bring it to our eating place so they can feed her what they can't eat.75

The Spanish classes, briefings, and meals were only part of the program; Ill1ch added another dimension to their education. The sisters have vivid memorles of him. He was an outspoken, blunt, honest man of conviction. He challenged the zeal and motives of the misslonarles with such comments as: "What right do you have to go to Latin America?" "What difference do you think you are going to make?" "They don't want your culture!" After one particularly heated exchange, Sister Elizabeth asked him why he was saying such awful things to them. He smiled and told them that he admired them for volunteering to serve in the jungles of Peru. 76

The students were encouraged to go into Cuernavaca to speak with the shop-keepers or the people on the streets.

75 Sister Elizabeth, Diary, ms., 23 August 1966, SSMO Archives.

76Sister Elizabeth, personal interview, 5 April 1990. 
Fleld trips to Mexico Clty for Independence Day, the place of the Three Clvilizations, the Museum of Anthropology and to Taxco expanded their education and provided much needed tlme for rest and recreation. The cultural programs and exhlblts Impressed the sisters with the beautiful traditlons of country. Everything was new; even the religious services they knew so well were filled with wonder in this new place.

The religlous servlces and observances caught the Imagination of the slsters. Thelr flrst experlence of a Mexican fiesta was on September 8, at the parlsh of Our Most Holy Lady of the Miracles where Father Ambrose is the parish priest in Cuernavaca:

For nine days preceding the feast and the two days following, the mood is one of fiesta. Every morning one awakes to LOUD music. Various members of the Center visited the area. One Sister commented the next morning about the crowds, fireworks, booth, church and decoratlons in it. On the latter, sister descrlbed the intricate designs $1 \mathrm{n}$ the bouquets, and how she wished that her vocabulary were a little more advanced when all at once, in one bouquet she made out the message. It wasn't an ejaculation in honor of our Blessed Mother like she thought but rather an ad for Superlor Beer. The others were of a like nature. 77

Sister Elizabeth's visit to the shrine of Our Lady of Guadalupe could not be captured in words:

77Sister Elizabeth, Diary, ms., 8 September 1966, SSMO Archives. 
There aren't really words to express my love and devotion I experienced at the Shrine of Our Lady. To see the tilma of Juan Diego- and know the story is one thing-but to be there in front of it-knowing that Our Lady chose these people as her own-and see her beautiful flgure palnted on that cloth so many hundreds of years ago-truly deepened my faith. 78

The celebration of the feast of All Souls' Day (November 2) was a completely new experlence for the sisters. In Mexico, famll les come to the graves to clean and to decorate the tombs with flowers and candles:

Brooms and buckets of water were used to scrub and shine these tombs. The poor had only a wooden cross on theirs, but they made a fresh mound of dirt that was carefully smoothed out. Water was poured on top to help smooth our the hard clods. After this flowers were arranged in beautiful designs and candles added to the grave. On the next day the famlly would gather in the afternoon and pray and wait at the grave until the priest came to bless it.

In years past there was a lot of drinking and eating as the food was placed on the graves of the dead, but because of abuse this has been outlawed and the people are coming to understand the Christian concept of death. We did not observe any food on the graves and the entire tone of the day was one of reverence and love.79

Only a few short weeks of language school remalned. The sisters were getting anxious:

78 Ibid., 17 September 1966.

79 Sister Elizabeth to Sister Dolorosa, n.d. SSMO Archives

80 Mother Angela to Sister Dolorosa, n.d. SSMO Archives. 
Pray for us that we may go to our people and new home with an understanding of them and $a$ willingness to accept their standards. We can hardly walt to reach our new mission. We hope to be there by Christmas. 80

December 16 was the last day at the language school:

It held much excitement and sadness as we sald farewell to all. There were many tears-and it was hard to leave Mexlco as well as our classmates. 81

The following day, Father Ambrose and Father Charles took them to Mexlco Clty to catch their plane for Lima. After checking their luggage, the priests drove them through Zocolo to see the lights. Father Ambrose presented them with a bouquet of red roses as they took one more step toward thelr final destination- Tamshiyacu. Nine of their classmates were also on board; two would join them in Peru and the others went on to other destinations.

${ }^{81}$ Sister Elizabeth, Diary, ms., 16 December 1966. 


\section{CHAPTER IV}

\section{ARRIVAL IN LIMA}

The sisters arrived in Peru just as the season of summer was beglnnlng and were met by Father Kennard and Brother Bill McCarthy, a Marianist brother, at the airport in Lima.

Fr. was so excited and anxious about us because we were not in our veils and habits. He feared we would have trouble with our luggage-that they might not let it go through immigration. When we got to the inspection center-Fr. told them we were Sisters going to be missionaries in the Jungle of Peru. The man asked us if that was true-when we said Yes-he never opened one thing and gave us free passage. Others had their suitcases checked from one end to the other. 82

Another Marianist brother, Brother Francis, was waiting outside with a truck to take their luggage. The brothers took them to San Antonio, the Marianist High School in Callao. After they had freshened up, Father of fered a Mass of Thanksglving for thelr safe arrival. Later in the morning, they went to the section of Lima called San Isidro where the Marianist sisters lived:

There were seven sisters in this big beautiful mansion made into a convent. This was one of

82 Sister Elizabeth, Diary, ms., 20 December 1966, SSMO Archives. 
the wealthy schools of LIma and the slsters were just closing school. It was a bad time to have 4 visiting Sisters come to live with them for a month. 83

The month was $f l l l e d$ with getting a better understanding of the culture and people of Peru, meetling new frlends, celebrating Christmas and red tape. Much time was spent trylng to get the legal affalrs settled in order to teach in Peru:

This morning (December 23) we spent the $t$ ime going over our credits and degrees with Fr. Kennard so that all our red tape could soon be started. 84

They soon discovered that Lima was a city of contrast. Shortly after they had visited a Marianist high school in a very wealthy section, they visited a barrlada:

These are the slum areas and Lima has many!

Poverty is unbel ievable! Two Sisters (Germans)

live out there too. They have no water, no

lights, no gas. One sister was ill-they dress

in heavy long habits and teach the girls to sew.

I (Sister Elizabeth) can't Imagine anyone staying healthy there.85

Midnight Mass was celebrated in the Sisters' Chapel by Father Kennard. The homily was on peace," the peace that Jesus came to glve".86 After Mass, they had a

${ }^{83}$ Ibid., 14 December 1966

84 Ibid.

85Ibid., 24 December 1966.

86 Ibid. 
small celebration with the Marianlst sisters. The

Marlanlsts invlted the Oregon sisters to open glfts:

They had wrapped several gifts for each one of us and one that was especially remembered was a small Spanish Bible. We shall always remember our first Christmas in Peru.87

The sisters had their first taste of Peruvian food at an exclusive restaurant called "Rosita del Rios" as the guests of a couple.

The food was excellent and we had so many new dishes to try. One dish Sr. Kateri thought was so good was fried blood with onlons. I (Sister Elizabeth) enjoyed her expression when she found out what it was. We also had our first taste of Ceviche which is white $f$ ish soaked in lemon juice with onion and parsley. I didn't think I could eat it because it was uncooked but it became one of my favorite dishes. We had beans, rlce, chicken, crillo, salsa, sweet and sour pork, fried bananas and many more first tastes! So-o-good. I'll be a good Peruvlan.88

The day after Chrlstmas, the sisters left for Naplo, a beach just outside of Lima. While vacationing for a week, they learned how to crab. They didn't realize how strong the sun was until Sister Elizabeth got sick from sunstroke.

The sisters had to bide their time when they returned to Lima in January 1967. The government still had not recognized their degrees. Father Kennard told them that

87 Ibid.

88Ibid., 25 December 1966. 
they could leave for Iqultos on January 14. Mother Angela would remain with Father and join the others later.89

Slsters Margaret Mary, Katerl and El lzabeth flew by Peruvian airlines $1,000 \mathrm{miles}$ across the Andes Mountains to Iquitos, a large port clty on the Amazon Rlver.

I (Slster El |zabeth) shall never forget the moment we stepped off the plane in Iqultos. It was like we were put into a hot furnace. The heat was stifling. 90

They were greeted by Brothers Bill, Allan and Vlvalde and taken to the Franciscan Center to stay over the weekend until Father Kalberer could come from Tamshiyacu. While they waited for his arrival, they explored the clty:

We had fun that first week-end golng to see the tropical zoo. Iquitos proved to be a very

fascinating town and we also proved interesting to the merchants and people there. We were the first Nuns to ever come in modern garb. People were happy to have us come and work among them. 91

The most common means of transportatlon from Iqultos to Tamshiyacu was a four hour boat ride up the Amazon River. On Monday, January 17, Father Jim Kalberer arrived In a large boat to take the slsters to Tamshlyacu:

It was so good to see him. We found out that one of the delays for Father coming to get us was the fact that the Spanish Nuns there before us-had literally stripped the house. They took

89 Ibid., 11 January 1967.

90 Ibid., 14 January 1967.

91 Ibid. 
all light fixtures -wiring-cupboards -beds, etc. Therefore, we had to wait until the house got wired and Father wanted us to wait longer until bedsteads could be made for us. We begged hlm to take us out so we could help $f 1 x$ the house and he agreed!92

The scenery along the river bank was described in vivid detail in an earlier Sentinel article:

Thatched houses appear from time to $t$ lme near the water's edge and here entire families live in one or two rooms and eke out an existence raising bananas, yucca, a few chickens and plgs.

There is little wildlife seen from the river, since the traffic keeps it back in the jungle and crocodile limit their activities to the smaller tributaries. 93

A small Peruvian moorage was used by the parish as a dock for boat traffic. Visitors to Tamshiyacu had to carry their luggage through the army compound, up the steps carved into the hillsides and find their way to the village. The sisters quickly made the best of their humble situation:

We put new mattresses (straw) on the floor after we cleaned the room thoroughly so we had no tarantulas or snakes! 94

Two of the Marianists brothers, Bill and Allan, who had accompanied them up the Amazon spent the next few days

92Ibid., 17 January 1967.

93 Gorman Hogan, "Tamshiyacu:'An Inspirational Treat" "Catholic Sentinel [Oregon] 4 February 1966, sec. A: 14. Archives.

94Sister Elizabeth, Diary, ms., 17 January 1967, SSMO 
putting up bedroom walls in the make-shift convent. The one large narrow room was divided into mall cubicles for the sisters. Eventually, they added orange terrycloth curtains as doors.

They (the brothers) also put up curtaln rods and we made and hung curtains. They found a standing narrow closet and since we had so few clothes (three outfits) it was large enough. Later we flxed boxes for shelves. With thatand the coming of bed frames made right in our village- our bedroom was a ball room!95

They did not have any furniture at first. Gradually, Father Kalberer was able to find a rocking chair and two other chairs for a little parlor. Later, they got a kitchen table and four more chairs. The sisters were exclted to find a refrigerator:

It was a delight when we reallzed that the Sisters had left a Frlg- but when we opened itcockroaches jumped out. The Frig was broken down and had not worked for them either!96

It would be some time before they could afford to buy a new one. 97

Mother Angela finally joined the trio around the middle of February. The mission's official staff was now complete: Fathers Kennard and Kalberer, the four sisters and Claire Beauchesne and Nicol Pilon, the two Canadian

$$
\begin{aligned}
& 95 \text { Ibid. } \\
& 96 \text { Ibid., } 14 \text { January } 1967 .
\end{aligned}
$$

97 Ibid. A new kerosene refrigerator had to be imported from Sweden at the cost of $\$ 900$. 
nurses. An "unofflclal" staff member was Leonides, a young Peruvlan who was a deaf-mute.

He was to become our loyal frlend and the handy man who fixed everything for us. There was very little he could not figure out. He never went to school but the devlsed his own sign language and we could really communlcate very well with hlm. Sr. Kateri could read hls slgns best of al 1.98

The sisters had until March to get adjusted to the jungle and the language before registration had to begin for the new term. One of the hardest things was learning to IIve with the ants, splders and cockroaches. Every Saturday, two of the sisters swept the walls and ceillings, the third would carry the water and the fourth would mop the floors with brooms in an attempt to control the insect population.99 The sisters also had the opportunity to test their language skills:

The children came to the house and we would ask them to take us around the village and explain things to us. One of our big reasons for doing this was that it was so easy to talk to klds. They laughed at our mistakes in Spanish but really wanted to help us. They had quite a few words different than Mexico-and to our rellefthey spoke slowly-almost in a singing way.

But every night, the teen agers would gather on our front porch and Sr. Katerl played her gultar and we learned to sing their songs. These

98 Ibid., n.d. January 1967

99 Ibid., 28 February 1967. 
evenings did a lot to strengthen our language and we also formed frlendships. 100

These first few weeks also provlded the tlme to give the people of Tamshlyacu a different perspective on religious women :

The people were a $\mid$ ittle distant at first because we were in modern Nun's clothes. What really made them accept us was the fact that we carried our own parcels from the boat and stores. Also, we stopped at their homes to $v$ isit them and they were amazed! The Spanish Nuns had never carried a thing but had the people carry all their things and walk behind them. Also, they never paid a tip and we did. There was a really long way from boat to our house- probably 6 blocks. When we carried our things and gave a tip to child who helped us- we were considered $O . K$. In fact-within 3 months when school started, we were greatly revered by most. They loved us as we did them.101

100 Ib id.

101 Ibid. 


\section{CHAPTER V}

\section{THE FIRST YEAR AT THE MISSION}

Registration for the next school year was held on March 16 for the grade school and March 21 for the high school. Father Kennard went to the State Department earller in the month to get the contracts for the sisters and to get permission to open the high school. Upon his return to the village he met with the sisters to explain the arrangements he made with the Department of Education:

In Peru- all schools are public-that is- the state pays all wages and gives a certain amount of money for supplies. We had to bulld the school but they would pay all salaries. We had to follow the state Course of study but the Cathollc Religion was likewlse a requlrement. So in essence-we had a private public school.102

The need for quality teachers and school in Peru was tremendous. An estimated 500,000 Peruvian children were illiterate in 1963.103 Education was an important issue in the elections of that year. Presidential candidate Fernando Belaunde Terry supported a bill to provlde free education for children from elementary school through college. The projected budget for the plan was $\$ 770$

102Sister Elizabeth, Diary, ms., 14 March 1967. SSMO Archlves. 30.

103"Peru: Big Winner," Newsweek, 30 December 1963, 
mlllion. After he won the election, Belaunde won general agreement from the opposition leaders for a broad program of social and economlc reforms before his inauguration, but congressional members refused to go along with the program.104 The government willingly accepted assistance from missionaries:

Peru was so happy to get another High School in the jungle that they cooperated extremely well with Father in getting us established. The only $\mathrm{H}$. Schools there were run by Missionary groups. The reason for this: the Govt. never gave enough money to run a school. No books were bought by the State- no desks furnished. Really all they did was pay teachers and give enough money to buy chalk and a little paper and pencils. Soas a result, only missionaries with funds from home, could keep a H. S. In operation.105

The sisters accepted the following responsibilities:

Sister Elizabeth was the princlpal of the High School, Mother Angela was the principal of the Girls Grade School, Sister Kateri was the Religion Teacher in all three of the other schools in the area: Boys grade School, the Primary School at Santa Rosa and at the Agricultural High school and Slster Margaret Mary was the Secretary and Treasurer

104"Peru: Revolution Within the Law," Iime, 2 October 1964,71 .

105Sister Elizabeth, Diary, ms., 14 March 1967, SSMO Archives. 
of the Hlgh School. The salarles were "somethling llke \$35 to $\$ 45$ a month. That was really money there."106

Sister Margaret Mary spent most of her tlme fllling out government forms. She felt as though she was "operating a bureau of investigation".107

Part of her work is to see that all the students have five different certificates which include fingerprints as well as photos. The teacher must submit all teaching credentials, transcripts and degrees from all levels of learning after grade school. Part of Sister's time is occupied with becoming acquainted with the complex method ( $o f$ ) bookkeeping. She is sure she will be able to tackle the problems of income tax forms when she returns to the States. 108

Matriculation (registration) was a complex task. A parent or guardian presented the birth or baptismal certiflcate as well as the certiflcate of the preceding year to the school. Using this information, the teachers filled out a lengthy form to be sent into the office of Education. Most of the people did not know how to spell their names. As a result, often there was more than one spelling of a student's name on record. The government rejected a registration form if even an accent mark was in

106 Ibid.

107"School Classes At Home Were Never Like This," Catholic Sentinel [Oregon] 9 June 1967, sec. A: 19. 
the wrong place. The enrollment at the Girls' Grade school was 272 students.109

Registration at the high school was the first experience the people had of higher education:

People came slowly at flrst-not knowlng what to expect-whether they had to pay a lot. When we told them the Mission was supplying the books if they took good care of them-word spread fast. Some young men, 20-22 (years old) came at evening time to ask if there was an age $1 \mathrm{imit-we}$ said no- as long as they wanted to study. Some of these young men and women were 6 and 7 years out of Grade School and found it hard to quite (sic) working as a man in the fields and sit in school.

We had 42 Freshmen enrolled-ages varied from 12 to 22.110

Before classes began, the sisters had to attend meetings in Iquitos. The sisters left Tamshiyacu at $3 \mathrm{a} \cdot \mathrm{m}$. on a colectivo, a large boat with a straw roof over it. The villagers packed their produce in the boat to sell in Iquitos. Passengers had no special section to themselves; they had to $f$ ind a place among the produce. They arrlved at $6 \mathrm{a} . \mathrm{m}$. and the meet lngs lasted from 12:30 to $4: 30$. The meetings were comprlsed of speeches

109 Sister Elizabeth, Diary, ms., 16 March 1967, SSMO Archives.

110 Ibid., 21 March 1967. 
organized by the Education office. A teacher could not mlss more than one day wlthout notlfylng the offlce.111 The first day of classes for all of the sisters was April 3. The grade school had all of its teachers: "Two were new and inexperienced but several were mothers from the village."112 The high school did not have any teachers except Sister Elizabeth because the teachers were out on strike and they had no books, nor desks. The high school was located in the Community Center; one long room was divided by a bamboo wall. Eventually, the high school situation stabilized, teachers were hired and the bare essentials for teaching were purchased.

The style of education was quite simple in Peru. Each student had a composition book for every subject. The teacher wrote notes on the board and the student copied them Into the composition book. Everythlng had to be memorized.

The first month of school went quickly. In May, Sister Elizabeth and Mother Angela attended their first meeting of the Fernando Lores Club as principals. There were only two clubs in the village; this was more

111 Sister Angela, personal interview, 10 March 1990. 112 Sister Elizabeth, Diary, ms., 16 March 1967, SSMO Archives. 
elite!113 The mayor of the v1llage invited Father Kennard, the sisters and the teachers to a meeting. There was tension in the village because of the high school. Some were angry because enrollment in the Agricultural School dropped because of the new high school. The evening was an unpleasant one for Father; the sisters left wonderling how things would fare for them.114 The sisters' fears eased as the official inauguratlon of the new "Colegio National Santa Maria del Amazona" went well just two days after the meeting with the mayor. The Director General of Education, Andres Cardo Franco, and two unidentified men from Columbia College in New York came to the ceremony.115 The sisters' fears continued to fade as parents attended the Padres de Familia (P.T.A.) meetings of both the primary and high school. By the end of the month, parents and teachers were attending the free English classes offered in the evening.

By June, the sisters finally had permission to adapt their habits to the realities of the jungles of Peru. It was evident by March that the habits designed in the Pacific Northwest were unsuitable for the jungles of Peru.

$$
\begin{aligned}
& 113 \text { Ibid., } 1 \text { May } 1967 . \\
& 114 \text { Ibid., } 7 \text { May } 1967 . \\
& 115 \text { Ibid., } 9 \text { May } 1967 .
\end{aligned}
$$


Green mold grew on the slsters shoes. They had to put thelr shoes in the sunshine frequently to get rid of the mold. Because of the heat and humldity, the sisters needed to change thelr clothes two or three tlmes a day. Without electriclty, the slsters had to use irons with hot coals to press the habits. The Council, at first, dld not support the request that the misslonarles deslgn thelr own hablts. The Council wanted the pattern to be designed at the Motherhouse.116 The Council finally allowed the missionaries to select something that was practical:
We were able to get some light gray dacron material and made simple dresses with white collars. These could be rinsed out and hung on our back porch and they dried with the hour- no ironing needed! We likewise had thin little veils made at the same time-same material.117

The Council refused the request of the missionaries to take off their veils and continued to mandate that the missionaries had to wear stockings with the mission habit.118 The Council had the opinion that the missionaries were to give example to the people: "Their femininity requires that they wear veils and

116 Council Minutes, 25 March 1967, SSMO Archives.

117 Sister Elizabeth, Diary, ms., n.d. June 1967, SSMO Archives.

118 Councli Minutes 25 March 1967, SSMO Archives. 
stockings." 119 The community in Beaverton was too inexperienced in $\mathrm{mlssions}$ and was too far removed from the reallty of the harsh, jungle climate to understand the requests of the missionarles.

The reality of the harsh climate took its toll on the health of Sister Elizabeth in July. Whlle travelling to Iquitos in a collectivo, Sister was exposed to the intense heat of the sun. On July 3 , she woke up with the left side of her face paralyzed. She remained in Iquitos for one month receiving shock treatments to improve her condition. A sister nurse from Lima advised that sister El lzabeth go to Lima because the nurse recognlzed that she had Bell's Palsy. Sister's spirits fell as the months of recovery dragged on:

I had hoped so hoped it would be only 3 mo.-now it looks closer to 5 or 6 ! It seems like my mouth and eye have gone back to normal just part way and now nothing seems to happen. The nurse was a little disgusted with me as she thought I wasn't doing the exercises at home but I am! The $\mathrm{Dr}$. has come in very often lately-don't know if he is concerned also. I was so disappointed. I finally wrote to $M$. Angela as they'll have to plan H. S. reports without me. I'll be lucky if 
I'm home for Christmas unless a miracle happens. 120

Sister Elizabeth's spirits improved with the generoslty of some of the religlous men and women in Lima. Some slsters who were teaching in Lima asked their students:

\begin{abstract}
for vitamins and antibotlcs (sic) for us in the jungle and did we ever receive medicine! Many fathers are doctors and we got all their samples. I worked days packing (not an inch space let empty) 13 boxes- large carton size. The Air Force will fly it all for free-aren't we lucky? Our nurses will be so happy as we were down to rock bottom- especially on these two items. The Franciscan Bro. came to take it to the Air Force and today two more big boxes arrived. They will probably keep coming as long as they see me around.121
\end{abstract}

She also had visitors from the mission. Mother Angela spent her vacation there in August and one of the nurses, Claire Beauchesne stopped on her way back to Canada. Sister returned to Tamshiyacu on October 22 and was greeted warmly by her sisters and students. Even though her face was still distorted, she went back to teaching.

The first school year was rapidly drawing to a close. Town officials came to celebrate the end of the year with the sisters on December 19. The sisters now had vacation time to rest their minds, bodies and souls.

Their first Christmas in the jungle was filled with simple beauty: 
We had Midnight Mass in our Church-preceded by the "Pastores". The meaning of Christmas here is strictly religious. They had a rather long pageant the eve of Christmas where they sing, dance and act out the story of Christ's Birth. The Indians are very much a part of it-but it is their way of foretelling His Birth. There are no cribs- no presents- no tree! We were amazed! They gather a few greens and light a homemade oil light and then if they had a little plastic figure of anything- dog- horse, etc. it was put out by the greens. No figures at all! We had a beautiful little Mexican Crib Set in bright colors that we put up in our house and of course- there was a nlce large one in the church. We irvited the children to come visit our crib and bring their mothers, which ever so many did. We encouraged them to say a little prayer to the Baby Jesus and then treated them to some candy we had saved. I think that it was the first Christmas I ever saw poverty- we who were so used to speclal treats no matter how poor our families were-we really saw it here. Yet, I kept thinking how much more these people had spiritually. No materialism of any kind! Christmas was Jesus birth (sic) and a day to give special thanks-that was all. We certainly did not let anyone see the little glfts we had made or purchased or saved ( $f$ rom U.S.A.) for each other that 1st. Xmas. 122

During the rest of vacation, each of the sisters spent some time away from the mlssion resting, travelling and going on retreat. They needed a break from the demands of the mission and the jungle climate.

122 Sister Elizabeth, Diary, ms., 25 December 1967, SSMO Archives. 


\section{CHAPTER VI}

\section{THE SECOND YEAR AT THE MISSION}

By the middle of February 1968, all the slsters were back at the mission. Two Australian priests came to the mission to give the sisters a retreat and to spend their vacations visiting the mission. Father Kalberer returned from a visit home to Oregon. He spent some time at the Motherhouse showing the community slides of the mission. He brought the sisters their new office books (prayer books) and word that they could wear skirts and blouses since they could no longer find the gray materlal they had been using for habits.122

The first day of school was on April 1. Mother Angela had 286 students registered. Improvements had been made over the vacation- outdoor bathrooms and a typewriter for Sister Margaret Mary. The high school enrollment had increased to 95: 34 in the second year and 61 in the freshmen class. With vacation ending and the beginning of new school year approaching, the sisters returned to their

122 Sister Elizabeth Nosack, Diary, ms., 29 March 1968, SSMO Archives. 
dally schedule:

No $r$ islng bell rings but everyone gets up at six a.m. We have morning prayer together at 6:45 a.m. Breakfast follows as soon as it is ready. By the time dishes are washed, the teachers in my school (the primary school) have begun to arrive. I (Mother Angela) ring a first bell at $7: 30 \mathrm{a} \cdot \mathrm{m}$. but the $8 \mathrm{a} \cdot \mathrm{m}$. bell begins the school day. Classes are from 8-9:45 with a halt hour recess, followed by classes until $11 \mathrm{a} . \mathrm{m}$. for the first four grades and until 12 for the others. Dinner is about 12 . Usually by 1 p.m. we are ready to stretch out for a siesta. At $2: 30$ p.m. I again ring the first bell but the three $O^{\prime}$ clock bell announces the hour for classes from $3-5 \mathrm{p} . \mathrm{m}$. The youngsters must sweep their classroom walks and the patio. Usually it is 5:30 p.m. before school can be locked. After this we take showers and get ready for Mass which is at $6: 30 \mathrm{p} . \mathrm{m}$. Following Mass is supper, usually shortly after 7 p.m. By the time the meal is over and dishes $f$ inished, it is between 8 and $8: 30$ p.m. Our retiring time depends upon how exhausted we are. It is a long day, especially when the temperature is high.123

The school year seemed to go smoothly; no mention of tensions or trials was made. Other concerns, personal, communal and national captured the sisters' attention and were recorded in their letters and diary.

Sister El izabeth was concerned about the declining health of her mother. Her mother died on May 6. Sister received the telegram that same day because of the kindness of the Army garrison nearby. Father Kennard

123Mother Angela to Sister Dolorosa, 21 May 1968, SSMO Archives. 
offered to have her go home for the funeral but she declined because of the expense.124

Each day in the jungle challenged the courage of the sisters:

About two weeks ago as I (Sister Margaret Mary) was about to open a door in the hallway. I saw a large eight inch tarantula. I was going to answer the door and when I saw the tarantula I said "An animal!" Father Kennard who had knocked at the door replied "I am no animal I'm a person!" When I opened the front door I sald to Father "Look!" He said "get a broom quickly!" So I called to Sister Kateri to get a flash light as our hall is poorly lighted. Well I killed my first tarantula and the only one we've seen in our convent also the largest we've seen in (the) time we've been here. Hope I can kill a snake as easy when the opportunity arises.125

Creativity and a sense of humor were effective

remedies to the ease the constant battle with the bugs:

The other day Sister Agnes Coussens (Sister Margaret Mary had chosen to go back to her baptismal name.) gave me (Sister Kateri) some peanut brittle. Not desiring to eat all of the piece at once I was faced with a dilemna. I hate to share my food with ants. Being in Iquitos there was the advantage of having a sink in my room. Using a water glass which I upturned, I placed the sweet stuff on top and partially filled the bowl with water. That fooled the ants and were they frustrated running around the edge of the water. But the following day the joke was on me. The stopper not being

124 Sister Elizabeth, Diary, ms., May 1968, SSMO Archives.

125Sister Agnes to Sister Dolorosa, 21 May 1968, SSMo Archives. 
placed $f \mid r m l y$ the water ran out. You guessed what happened! 126

The temperature had dropped from the usual 100 degrees to "freezing"- 58 to 60 degrees for a few days in May. The poor people were suffering because they had no blankets or sweaters. One student got up at $3 \mathrm{a} . \mathrm{m}$. and walked around to try to keep warm. The missionaries went through the clothes from the Bishops' Rellef Fund sorting out the warm clothes to give to the poorest families.127

The sisters kept in touch with the world outside of the jungle by means of the Voice of America. Sister Margaret Mary was listening quite frequentiy during the presidential primaries in the United States because she was an avid "Kennedy fan".

Wednesday morning June 5, I turned on Voice of America at 8:00 $0^{\prime} \mathrm{clock}$ and heard that Senator Robert Kennedy was shot after winning the primary election in California. We kept informed through the day by aur radio how his condition was. Thursday morning we heard he died. In memory of Kennedy's death there was only news about Kennedy and muslc on Voice of America on Thursday. I imagine everyone is almost glued to their television like when President John Kennedy died.128

126 Sister Kateri to Sisters, 2 December 1968, SSMO Archives.

127 Sister Elizabeth to Sister Dolorosa, 23 May 1968 , SSMO Archives.

${ }^{128}$ Sister Agnes to Sister Dolorosa, 6 June 1968, SSMO Archives. 
Sister Ellzabeth was in Iqultos at the tlme. A newspaper vendor, splt at her and sald "You kllled our frlend!

(Kennedy). Thls was the only antl-Amerlcan experlence any of the slsters had during their time in Peru. Later in the month, Sister Margaret Mary requested pages from Look and Llfe magazines regarding Kennedy's assasslnation.129

Requests from the missionaries were being handled by Sister Dolorosa, the new mission coordinator. She was asked by Mother Consilia to meet the day to day needs of the missionaries such as clothes hangers, a clothes line, a set of Office guldes for their Office Books, shoes, books, etc. The missionaries requested a variety of books to be sent to them. Titles included: Create, Everything About Money, Peanuts Cook Book, Open to the Spirit and Encounter Groups. Paperbacks were better to send because of the weight and the fact that the leather bindings had the tendency to mold.130

July was the month to celebrate the independence days of both the United States and Peru. The Americans at the mission celebrated the Fourth of July in style. They had hamburgers and fried potatoes. Father Kennard brought the

129 Mother Angela to Sister Dolorosa, 24 June 1968, SSMO Archlves

130 Sister Agnes to Sister Dolorosa, 21 May 1968, SSMO Archives. 
sisters a special drink called Leche de Monja, Nuns' MilK.131

Peruvian Independence Day (July 28) celebration was "modest" compared with the last year's events:

Beginning on the evening of July 27 and lasting until July 30 , each settlement has all sorts of patriotic celebration in honor of Peru's independence. In Tamshlyacu the celebrations consisted of all night dances on July 27-28; a military parade of a sort on July 28; games of Bingo in the evenings of July 27, 28, 29; races of all sorts for youngsters during the day of July 28; games of volleyball and football on July 28 and 29 . We tried to put in our appearance at most of these things to show our interest in the people.132

Each school had its own private program and there was no parade because of the government take over.133 Independence Day marked the beginning of the mid-year vacation which lasted until August 12 . Some of the vacation time was consumed by meetings:

During that time, our Bishop is having two or three days of meeting with the priest and sisters in the mission at Punchana, the mission center. Since all of the other Sisters are French Canadians and practically all of the priests, likewise, the meetings will probably be a mixture of French and Spanish-at least that

131 Sister Elizabeth, Diary, ms., 4 July 1968, SSMO Archives.

132Mother Angela to Sisters, 28 August 1968, SSMO Archives

133 Sister El izabeth, Diary, ms., 28 July 1968, SSMO Archives. 
has been our experlence when we have been with the group at a social event. We do not know what will be the topic of discussion but we were advlsed by the mission radio that the meetings are to be attended by all. Joy! Joy!134

Four days of government meetings began on August 29 for the primary schools. Mother Angela and one of her teachers went to Iquitos to attend. 135

The sisters took turns writing general letters to the community, their families and friends. These letters included $r i c h$ description of the religious festivals of the people:

This seems like a perfect time to write to all, as our three-day fiesta is just over. Our parish is named in honor of Our Lady's Nativity so the 8th (of September) is indeed commemorated. The celebration started on the eve of the feast with the traditional procession. The statue of Mary was carried to the home of the family chosen to be host to her.

The procession is rather solemn and there was music of a drum and violin in a minor key. When the statue is enthroned, the nightly vigil is kept. All come through the night to do a special dance to the Virgin. This dance is simple and they use a handkerchief to wave. At one point in the dance all pause, kneel and make their promise to Mary. It is a lovely religious gesture on the part of young and old al ike.

On the morning of the 8 th all were awakened by the military band from Iquitos that came to play for this day. They marched through the streets

134Mother Angela to Sister Dolorosa, 21 July 1968, SSMO Archives.

135 Ibid. 
playlng beautiful numbers- some religious, others not so.136

The band accompanied the procession from the house of the privileged family to the Church. After Mass, all were Invited to the family's house for a feast. The family was very poor but were generous in sharing the little they $\operatorname{had} 137$

The sisters were eagerly anticipating a visit from Mother Consilia in October. Mother Consilia arrived in Iquitos on October 18. She flew with Mother Angela to Tamshiyacu on October 20 .

October 20th was like Christmas for the four of us at Tamshiyacu. We had Mother Consilia with us. Also we opened the beautiful presents given by the different houses in our community, letters from home, and money sacrifices from the sisters at home.

During the period that Mother Mary Consilia visited at our convent the bathroom water tank went dry and we had to use the outside bathroom. We also carried all the water for the kitchen. We are now happy to report we have had several rain storms since Mother Consilia left us and the tanks are filled.138

Mother Consilia stayed for nine days at the mission experiencing the day to day lives of the missionaries.

136 Ibid.

137 Sister Elizabeth to Sisters, Family and Friends, 10 September 1968 , SSMO Archives.

138 Sister Agnes to Sisters, 18 November 1968, SSMO Archives. 
Mother was Impressed by the extreme poverty of the people and their warmth and graciousness: "I never shook so many hands." 139

It was a wonderful visit and she was such a good sport, especially when the bats started flying around in church and in the shower with her.

When she left, she cried because she thought we lived in such poverty. By that time we thought we had things pretty nice.140

During her visit, Mother Consilia expressed her concern about Sister Elizabeth's condltion. She wanted Sister to have American doctors examine her. Sister Elizabeth planned to leave during vacation (December)

I'm coming home in December for my Jubilee! (Twenty-tive years in the community) I can hardly believe it. I wrote only to my Dadhe'll be thrilled to death. Will stay for Jan and Feb at least! 141

All of the misslonaries were able to get excused from the jobs to see Mother Consilia of $f$ at the alrport on October 30. About six weeks later on December 19, Slster

Elizabeth flew to Portland.

$139 "$ "Superior Visits Misslon: Oregon Slsters In Peru Happy, Love the Work," Catholle Sentinel [Oregon] 29 November 1968, sec. A: 1 .

140 Sister Elizabeth, Diary, ms., 18 November 1968 , SSMO Archives.

141Sister Elizabeth to Sister Dolorosa, 29 November 1968, SSMO Archives. 
The school year ended the next day. After Christmas Mass, Mother Angela and Sister Margaret Mary left for Iquitos and continued on to Lima to study at the Language School in Branca. On December 30, Sister Kateri met her parents in Iquitos; they spent the next three weeks traveling in Lat in Amerlca. 


\section{CHAPTER VII}

\section{THE THIRD YEAR AT THE MISSION}

Sister Elizabeth's medical condition was quite serious. Her regular doctor recommended that she make an appointment with a group of specialists at the University of Oregon Medical School. There was a symposium on Bell's Palsy being held at the time; ninety doctors examined her because she had the most severe case of Bell's Palsy that any of them had seen. 142 Sister Elizabeth spent part of her vacation in Portland speaking to students at some of the grade schools staffed by the Sisters of St. Mary of Oregon. Students at St. John's School in Milwaukie sponsored a garage sale, movie and cake sales to raise $\$ 100$ for the mission school.143 Sister Elizabeth told the American students about the unsophisticated life of the children in Peru:

Scenes of U. S. citles and the rose test gardens in Portland's Washington Park, shown on

Viewmasters the sisters took to Peru have amazed their students. 1990.

142 Sister Elizabeth, personal interview, 5 April

143"Catholic Nuns Fights Poverty, Ignorance As Teachers in Feru." Oregonian [Oregonj 24 February 1969 , $\sec A: 10$. 
They can't belleve there are places like that. To these people who have never seen a park, it is astounding that there are people who have time to work just making something beautiful. They work so hard to get something to eat.144

Sister Elizabeth declined to talk about Amerlcan- Peruvian relations since American tuna boats were fired on by a Peruvian naval ship on February 15. She explained that the sisters were well accepted by the people and the people were grateful for the opportunity for an education.

People in Tamshiyacu ask us over and over why we left our wealthy country, with all its conveniences, to come down there where there is no running water and no sanitation. Our very presence, there, by example, does make a difference in the way they feel about the United States. 145

In a letter to the community, Mother Angela teasingly assured the sisters in Beaverton that she and Sister Agnes Coussens were not on vacation even though Sister Elizabeth was: they had a busy schedule at the language school in Lima. They did see Sister Kateri and her parents as they stopped in Lima occasionally during their travels. The Petites planned to spend their last days in Lima before leaving for the United States; Sister Kateri would then remain with the others until the language school ended. Mother Angela was hoping for about ten days of travel and

144 Ibid.

145 Ibid. 
rest before all went back to the mission; It would depend on how quickly their business matters were settled in LIma. 146

When Sister Elizabeth returned to Peru in March, she was accompanied by Barbara Whitford, a registered nurse from St. Cecilia's Parish in Beaverton who was volunteering for the mission. Barbara had known Sister Elizabeth as the physical education teacher at St. Mary of the Valley High School and had wanted to work somewhere with poor people since she finished nursing school. Barbara would replace Claire Beauchesne, one of the Canadian nurses. Sister Elizabeth was brlnging another addition to the mission a motion picture projector: "It will be the one bright light in the town".147 Sister made an appeal for donations to purchase medical supplies. It was less expensive and more convenient to buy the supplies in Lima than to buy and ship them from the United States.

Sister Eijzabeth and Barbara arrived earlier than expected in Peru on March 17. Because of the breakdown of the radio in Punchana, they had no means of contacting the mission. They remained in Punchana a few days waiting for

146Mother Angela to Mother Consilia and Sisters, 15 January 1969, SSMO Archives.

147"Tamshiyacu: Beaverton Nurse Joins Mission," Catholic Sentinel [Oregon] 14 March 1969, sec. A: 23. 
the missionaries to arrive. Sister Kateri stayed in Lima to help Barbara get her papers in order. By the end of March, all of them were back at the misslon.

Barbara lasted only one week at the mission:

It was such a culture shock and change for her, poor girl. She just could not accept the way people have to live- their poverty was repulsive to her- she could never love them as we do.

Also the tremendous responsibility she'd have as nurse was too much for her. 148

Through the generosity of the people of Oregon, Sister Elizabeth brought a movie projector, film-strip projector and slide attachment and view masters. The Canadian and German embassies provided free films to high schools. Every two weeks, four or five films arrived at the village: a mixture of educational and recreational ones.

The first movie we gave was history to our town. It was a Canadian Royal Mounted Police story. We invited all to come free and the hall was packed. When I (Sister Elizabeth) turned the movie on instead of the name first- it had 3 men riding on horseback toward us. They (the villagers) screamed and ran outside as they thought the horses were coming at them! I turned it of $f$ - and had to convince then it was only a picture. What a shock to them.149

148 Sister Elizabeth to Sister Dolorosa, 22 March 1969, SSMO Archives.

149 Sister Elizabeth, Diary, ms., 1 November 1969, SSMO Archives. 
Every Friday night, the sisters charged a small entrance fee to pay the postage on the fllms. The children lined up an hour ahead of time and then dashed in to sit on the floor in the front of the room.

There are always a few stray, wlde-eyed youngsters who do not have the money for a ticket. We make a compact. I glve them a ticket and they come work for us on Saturday. Or some of them will work on their farm and then bring us some yucca or bananas. 150

Students at St. Matthew's School in Hillsboro gave the film strip projector and the slide attachment to the mission. The slide attachment added a personal element to life in the village:

At the various fiesta we have taken colored slides and so are able to show these to the people. Recently we showed them at our P.T.A. meeting in the High School and it caused great excitement. Parents were so proud to see their own sons and daughters on the screen. They were not content unt!l I (Sister Elizabeth) did a re-run of all the silides. 151

A small group of boys came almost every Saturday and Sunday to sit looking at "television", which is what they called the viewmasters. The view masters were a gift from a family in Beaverton. The children of the village were fascinated by the world outside the jungle:

150 Sister El izabeth to Family and Friends, 30 November 1969 , SSMO Archives.

151 Ibid. 
At the rate the children use the view masters we shall have to solicit more as these are very loose and the roll does not slide easily. Of all the things we brought along, these machines have probably brought (the) most enjoyment to the little folk.152

Registration for the new year was under way. School began on April 1 with 286 students in the primary school and 101 students in the high school. Sister Elizabeth was disappointed in the enrollment for the high school. Whlle she was in the Unlted States, the teachers in the Agricultural High School were spreading rumors:

They told the people we weren't taking 1st year and that we were charging a large sum to register-plus buying many books. They also gave free room and board to all from outside areas. It is definitely sponsored by "someone" and I was upset to say the least.153

The school year got of to a good beginning in splte of the tension between the high school and the agricultural school. Attendance at the P.T.A. meeting was very good: 68 of the 76 families in the high school were represented. 154

152 Ibid.

${ }^{153}$ Sister Elizabeth to Sister Dolorosa, 22 April 1969, SSMO Archives.

154Sister Elizabeth, Diary, ms., April 1969, SSMO Archives. 
Sister Katerl's first graders added a Peruvlan flavor to the Gospels:

If you thought up to now that Jesus turned water into wine you are all mistaken. He changed it to chlcha (a drink made from corn). Besldes rice, chicken and yucca at the wedding feast of Cana the good people ate Quaker Oats and popsicles. 155

The bishop of the area called the missionarles together for two days of meetings in July.

The theme centered around 'What are we as missionaries doing here in Peru? Why did we come? There were fifty-one priests, brothers and sisters in attendance, We were divided into four groups to carry on the discussion of this topic. Later we met together and each group presented its conclusions. As the various secretarles read their minutes it was sort of amazing to note that each group had the same idea- we are here to form Christian Commun it $y .156$

The theme of the meetings echoed the debate that had been going on in American circles for the past two years. Ivan I ilich published an article in January of 1967 called "The Seamy Side of Charity". His basic premise was that American missionaries were forclng a "foreign Christian image, a foreign pastoral approach and a foreign political

155 Sister Kateri to Mother Consilia and Sisters, 9 May 1969, SSMO Archives.

156 Mother Angela to Mother Consilia and Sisters, 9 July 1969, SSMO Archives.

157 Gerald M. Costello, Mission to Latin America: The Successes and Fallures of a Twentieth Century Crusade, 285 . 
message" on the people of Latin Amerlca.157 The money and personnel from the United States were preventing the Church in Latin America from developing its own solutions to the problems that faced the reglon. Illlch made several strident statements wlthin the artlcle:

We must acknowledge that missioners can be pawns in a world ideological struggle and that it is blasphemous to us the gospel to prop up any social or political system. 158

The influx of U. S. missioners coincides with the Alliance for Progress, Camelot and CIA projects and looks like a baptism of these! 159

Latin America can no longer tolerate being a haven for U. S. I iberals who cannot make their point at home, an outlet for apostles too 'apostolic' to find their vocation as competent professionals within their own communities. 160

He ended the article asking why should more missionaries be sent. The article touched of heated debates.

No single document since Monsignor Casaroli's appeal at Notre Dame in 1961 on behalf of Pope John XXIII had so much impact on the future course of U. S. mission work in Latin Amer lca.161

In 1968, the number of Americans in Latin American had reached its peak : 3,391.162 The factors for the

158 Ibid.

159 Ibid., 287.

160 Ibid, . 288.

161 Ibid., 125.

162 Ibid., 164. 
gradual decline included the decreasing number of American religlous, the changes that occurred within the Church after Vatican Council II and the reality that the missionary's I ife was more free and Independent than the typical one in the United States. More missionarles were leaving religlous 1 ife and priesthood to marry compared to non-missionaries. 163

Illich would not retract his statements and remained an outspoken critic of the misslonary program. In 1969 , the Vatican formally forbade priests and sisters to study at his schocl in Cuernavaca. 164

On July 23, Sister Kateri asked for and was granted a medical leave of absence from the mission. The doctors in Iquitos suggested that she get some advice on the condition of her arthritis. Upon her return to the mission on September 17, her school supervisor gave her suggestions on the easiest method of completing the necessary paper work. This small token of kindness from a se lf-proclaimed Marxist who listened to Castro every night, hinted at acceptance of her contribution to the village. 165

163 Ibid., 165.

164 ibid., 130.

165 Sister Kateri, personal interview 10 March 1990. 
Mother Angela flew to the United States on September 25 to participate in the Chapter of Renewal. Meetings were scheduled In October, December and March. The purpose of the Chapter of Renewal was to examine every aspect of the life of the community in the light of Vatican Councll II.

Another school year was drawling to a close. Excitement grew during the final weeks as construction on the new high school progressed. It was hoped that classrooms would be ready by April 1970. The last day of school was December 23. After they had completed all the government forms, the sisters were ready to begin their vacation. 


\section{CHAPTER VIII}

\section{THE FOURTH YEAR AT THE MISSION}

The sisters were scattered about during vacation. Sister Elizabeth was in Lima for six weeks of language school. Mother Angela was in Oregon until February 25, 1970. She surprised Sister Elizabeth in Lima with a short vislt. Sister Kateri went to teach Indian tribes up-river from the mission. Two tribes llved in the area, the Yaguas and the Ticunas. Each tribe had its own language and neither spoke Spanish so Sister Kateri taught them both Spanish and religion. In exchange, the Indians taught Sister a profound meaning of graciousness and generosity:

It seemed that their poverty made them more generous because from their nothing, as it were, they shared something with us almost every day$f$ ish, bananas or other fruit. One day one of the parents gave us six eggs. he only had two hens and one was with chicks.

Being with the families at that little settlement was almost llke making a retreat. One recognized a whole different scale of values. The mutual assistance, harmony and simplicity of their lives couldn't help but impress themselves on an outsider.166

${ }^{166}$ Sister Kateri to Mother Consilia, Sisters and Friends, 7 June 1970 , SSMO Archives. 
Sister Kateri took her vacation in late March. Sister

Agnes remained at the mission unt/l February 21. She then left with Anna Hoganhart, a friend from the United States, to travel to Lima and Cuzco. Sister Elizabeth returned in the middle of February to organlze reglstration for the high school. After registering students each morning, Sister Elizabeth spent time in her garden:

I have started some pansies, daisies and parsley seeds and they are coming up in cans so I am worklng in the garden with some of the glrls. I'll try once more to get it looking beautlful but between the ants and pigs it is almost a lost cause. Tomorrow we are going to get some rich soil to put in the flower bed and then will bring in some of our beautiful wild ferns and lilies from the jungle. We have 4 orchids now! 167

She was also having success with baking bread; she discovered that the secret of baking bread in such a humid climate was in the proportion of yeast to flour.

Everyone returned by April to begin the new year. Enrollment was 294 for the primary and 144 for the high school.168

167Sister Elizabeth to Sister Dolorosa, 11 January 1970 , SSMO Archives. Archives

168 Sister Elizabeth, Diary, ms., 1 April 1970, SSMO 
Natural disasters ravaged the region in 1970. The Amazon River flooded in April, destroying the staple crops of bananas and yucca:

Thank God- that they at least have lots of $\mathrm{fish}$ just now. The government is giving out a little food-but it doesn't go very far. The next three months wlll be hard.169

In their suffering, the people turned to their traditional solutions:

One of our high school boys almost died this week from worms and malnutrition. His younger brother came to call me early in the morning as the older one was sick all night. I esister Elizabeth) sent him to the sister nurse and when we went to the house people were using witchcraft on him--pounding him and he was almost gone. The two priests went down and carried him up here to the clinic while Sr. held the I.V. She had put in him. After 2 days of constant care he was up and on the 4 th day even came to school.170

The Sisters were touched by the uncomplalning and cheerful disposition of the people during the floods. Reports indicated that it would be at least three more months before any crops would be planted. The sisters wondered what the people would eat in the interim.171

In June, an earthquake struck the Cordillera Blanca area, some eight hundred miles away from Tamshiyacu. Over

169Sister Elizabeth to Sister Dolorosa, 24 May 1970, SSMO Archives.

170 Ibid.

171 Ibid. 
60,000 people were killed, "the last few thousand dying from hunger and exposure." 172

It has really been terrible. The poor people are so trapped in the $\mathrm{mt}$. area- even in good situations it is hard to get in. Now with the railroad gone-airflelds gone it has been almost impossible to send help. We were so thrilled to hear of the quick response from the U. S. The first planes- the first crews! Great! Our people here are proud to tell us that the U. S. is helping so wonderfully.173

The next few months were very dry. By September, the sisters were anxiously awaiting rain:

Our one tank had been empty for a month or so, while the large one had to supply for all our needs, including showers and nature's needs. The water in it got quite low so that we had no running water in the house. Carrying buckets of water from outside to provide for household uses and for washing isn't just the easiest thing in the world. You may well imagine how we welcome the rain, especially after a dry period.174

September 24 was the feast of Our Lady of Mercy, the patron saint of the army. Father Kennard gave a fiesta for the army as a token of appreclation for the soldiers' help to the mission:

It turned out to be a beautiful day- the statue of Our Lady was carried in procession from the milltary base to the church with gun salutes on the way. Mass followed and a soldier was

172 Sister Elizabeth to Sister Dolorosa, 7 June 1970 , SSMO Archives.

${ }^{173}$ Ibid.

174Mother Angela to Sister Dolorosa, 10 September 1970 , SSMO Archives. 
marrled at the Mass. Another soldler found out after the Mass that his wife gave birth to his first son when the procession passed hls house! It was a great day for the Army. The climax of the day was the lovely meal prepared for all the soldiers, members of the mission, city council and those who prepared $1 \mathrm{t}$. In the evening, a dance was held to finish the day. 175

The sisters wanted to change the basic style of education by making copies of exercises for the students, The problem was, they did not have the means available to them in Peru:

Way back when, some of the sisters used to make their own hectograph pans. I wonder if you could get the recipe for this from someone. I though that if you could get a copy and send it to us, we could try to locate the ingredients. Should we not be able to get them down here, Sister Agnes $C$. could bring them back with her. We tried to get hectograph ink both in Iquitos and in Lima but it is not to be found. 176

Sister Agnes was planning to go to Oregon durlng Christmas vacation. Consistent with her thorough and orderly manner, she had been getting ready to go for months. Not a pin would be left out of place when she departed for her home visit. In May, she had already "been buying things that she will use as gifts when she

175Sister Elizabeth to Sisters, Relatives and Friends, October, 1970, SSMO Archives.

176Mother Angela to Sister Dolorosa, October 1970 , SSMO Archives. 
gets home, etc." 177

Her health was a concern to the other missionaries:

She is so thin that it is something to behold. I wish she could gain a few pounds but she seems not to be able to get the value out of her food. The rest of us would find ourselves without clothes to wear were we to eat an equal amount of food and sweets but sister surely has nothing to show for what she eats. Life should be a bit more universal in its treatment of us - no!178

Sister would be greatly missed by her companions. It was her task to do the shopping in Iquitos for food each week. She rose at $3 \mathrm{a} \cdot \mathrm{m}$, to go down to the river bank to wait for a colectivo. She arrived in Iquitos some four hours later. After buying the needed supplles and food, she returned to the mission by the same means.

When one of the missionaries was away, the others had to adjust to new responsibilities. Absences created humorous situations:

Tomorrow, Friday, both Srs. Betty (Elizabeth) and Agnes $C$. are going to Iquitos and may have to stay over until Monday to take care of their school papers, etc. That leaves Sr. Kater $\mathrm{I}$ and me (Mother Angela) to oversee the cooking durlng that time. Since our culinary ability is practically limited to opening cans of soup and making sandwiches, we do not welcome being left alone. The last time this happened to us, Sr. Kateri managed to buy two chickens. With the aid of a high school girl, she got them killed, plucked, cleaned and then prepared them by Archives.

177Mother Angela to Sister Dolorosa, 5 May 1970, SSMO ${ }^{178}$ Ibid. 
baking them very tastlly. At this time no chickens are avallable so God knows in what Sunday dinner will consist if one of the other two does not return in time to save the day. 179

The misslonarles generously gave of thelr time and talents whenever the people needed them. Mother Angela dabbled in the medical fleld as her "extracurricular project". She took care of small allments of her students in the primary school:

Many of them get horribly infected sores from scratching insect bites. Then there are the toothaches and sore eyes. The parents cannot afford to buy medicines to care for these problems. We inguired of a druggist re-the sores and he sold us an excellent ointment which usually draws out the infection after two applications. Then I put on mercurochrome to dry up the sore. We use boric acid for sore eyes and got a medicine for the teeth problems. Now, every recess I have a line up of youngsters waiting to get their particular ailment cured. It is true that some come more for attention than real need but the majority who wait their turn need help.180

Sister Elizabeth took a special Interest in a nine year-old boy who contracted pollo at the age of $n$ Ine months. The boy's father died when the boy was just one and a half years old and the boy had not received any treatment:

The boy is really alert and I'm teaching him to read and write a little each day. He crawls on

179 Mother Angela to Sister Dolorosa, 10 September 1970, SSMO Archlves.

180 Ibid. 
all fours as his legs are doubled at the knee. Some time ago I worked at getting $\mathrm{hlm}$ into the large polio hospital in Lima but they are crowded and only accept 9 from Iqultos. He is on the walting list but this week-end we struck luck I think! The wlfe of the General of all Mlitary forces here in Iquitos has a commlttee formed to help these polio victims. I went to her yesterday about our little boy- took him to see her and also to a $\mathrm{Dr}$. To make a long story short- we now have the services of a Dr.specialist in polio-who studied 8 years in New Jersey and worked 2 years in Florida on polio.181

Word from the Motherhouse was slow in coming throughout the year. The missionaries were interested in the changes in assignments of the sisters to various schools, the meetings and discussions of the Chapter of Renewal and the health and welfare of those at home. It was difflcult for the mlssionarles to be so far away. Some of their friends within the community had left and the future of others looked uncertain. Letters from home helped keep them in touch with the community. Letters and packages from Beaverton were taking months to arrlve. In the past, the sisters numbered their letters to see how many were actually getting through. Packages of books cleared customs without much delay; packages of other items were opened and sometimes destroyed and the sisters still had to pay the duties.

181 Sister Elizabeth to Sister Dolorosa, 16 Ausgust 1970, SSMO Archlves. 
Yet another year in the jungle was drawing to completion. The hope to move into the new high school in April dlssolved because of lack of funds. It was over half way finished and some of the materials were just walting for the workmen to use them; the slsters were hoplng that "the last collection at home will enable Father to continue and finish this dream".182 After Christmas, Sister Agnes left for her home visit and the others left the jungle for rest, relaxation and retreat.

182 Sister Elizabeth to Sister Dolorosa, October 1970 , SSMO Archives. 


\section{CHAPTER IX}

\section{THE FIFTH YEAR AT THE MISSION}

Mother Angela and Slster Katerl spent part of thelr vacation staylng with some Ir lsh Columban slsters in a poor barrlada, outslde of Llma. They experlenced another side of poverty in Peru:

One day the bus was so crowded that I (Mother Angela) could not open my purse to put in the change from the fare. For quite a distance I had to stand at about a 45 degree angle, bending backward because of lack of space. We must walk several blocks after we leave the bus- not on paved sldewalks but on rocky roads; the area had been covered by the rlver many years ago. A couple of tlme we returned in seml-darkness and found walking really difflcult. Llving in a poor area like thls makes one have a deeper sympathy for the people and also for the prlests and slsters who are worklng wlth them.183

Sister Elizabeth kept busy sewing and doing all klnds of odd Jobs she had put of $f$ because of school. She made bathrobes and pajamas for the others as Chrlstmas presents. (The slsters declded not to celebrate Chrlstmas untll Slster Agnes returned.) Hlgh school glrls used the left over material to make children's clothes and baby

183Mother Angela to Sister Dolorosa, 9 January 1971 , SSMO Archlves. 
quilts. Sister Elizabeth left for her vacation when Mother Angela and Sister Kateri returned after their retreat.

Sister Agnes was very busy durlng her home visit. She underwent surgery on both of her legs for varicose velins. After she had recovered from both surgeries, she vislted every one of the schools staffed by the communlty in Oregon and Washlington. After visiting her family in the Portland area, she travelled to San Franclsco to vislt her slster. Slster Agnes enjoyed seeing the typlcal tourlst slghts, China Town, St. Mary's Cathedral, the Golden Gate Brldge and at Flsherman's Wharf she watched "the Hipples makling beaut 1 ful crafts such as tooled belts, purses, plctures etc."184 Sigter took 133 pounds of extra luggage with her on the flight out of San Franclsco:

I was carrying such items as mlcroscopes, science material, charts for teaching rellgion, baby clothes that two Altar Society groups in the States were sending with me for the poor chlldren. Also I was carrying many palrs of shoes. Shoes are one item we can't buy here in Peru as the stores don't carry our slzes.185

184 Sister Agnes to Sisters, Friends and Students, 18 April 1971, SSMO Archives.

185 Ibid. 
Just as the new school year was about to begln, the threat of another flood loomed:

According to the radio, the river has four more inches to go to reach last year's flood state at the end of April of mid-May. It won't take long to reach and surpass that mark. We've still got the rains during April and May to go. Imagine the hardship for the people. Tamshiyacu, itself, doesn't suffer too much but the surrounding villages all but float away. People are frantically trying to save their yuca (sic). I fear it's going to be a tough year, again, for them. 186

The rains came in April. Most of the houses in the village were built on stilts; people entered and left their homes using canoes. The water boa was especially dangerous in the flood waters. Familles who had small chlldren left their farms to move to high ground because they feared that the boas would eat the children. Many children could not afford the uniforms and shoes needed to go to school; the sisters loaned money to as many families as possible from the donation fund. It would take months before crops could be planted. The fruits trees had to be replanted and the farmers would have to wait years for a harvest. 187

1865ister Elizabeth to Sister Gemma, 25 April 1971, SSMO Archives. 
In May, Mother Angela started a breakfast program for the students in her school. Men of the vlllage built a "Kltchen" measurlng three feet by $f$ lve feet where the women could prepare the oatmeal and serve It with milk and sugar :

The parents must pay 5 soles (equivalent of $\$ .13$ U. S. Money) monthly, regardless of how many children they have in school. Some parents felt this was too expensive but realized that the women who prepare the breakfast must be paid. I am sure not all will pay but we can use some of the money that the youngsters in the schools are sacrificing for us. I am certain the program will present problems but it will be worth the effort if the youngsters, many of whom come to school without breakfast, will have something to eat. We are able to get sugar, powdered milk and rolled oats from public health by requesting it .188

The mosquito population increased with the level of the river and played havoc with the missionaries. Each morning they awoke to legs that looked "like pin cushions". After several months of this, Slster Ellzabeth bought an electric mosquito destroyer as a surprise for the others. They had a custom of buying a glft that everyone could use for their birthdays. She planned to plug it in at $6 \mathrm{p} . \mathrm{m}$. and she hoped that it would continue

188Mother Angela to Sister Dolorosa, 29 April, 1971, SSMO Archives. 
to work at least ten hours after the electrlcity went of at 11 P.m. 189

Slster Agnes had been able to purchase most of the food needed at Iquitos. The sisters had made arrangements to buy meat from a prlest of the nelghboring village.

Delivery happened whenever the posslbllity presented itself. The mission plane came to pick up Sister Kateri on a Sunday afternoon in June and delivered the meat at the same time! Leonides, the deaf-mute who worked at the mission, sawed and cut the meat under the direction of Sister Elizabeth and the Betty Crocker Cookbook. Sister Agnes "helped hold the beast" while Mother Angela marked and bagged each piece. 190

Independence Day in July was planned, rehearsed and celebrated with great enthusiasm:

During this past week, we spent two afternoons practicing marching in preparation for our Independerice Day, July 28. This will continue until the day itself. Beginning this Monday we have daily speeches given by the teachers on the successive stages of development throughout the history of the country. The titles are sent out from the school office in Lima.191

189Sister Elizabeth to Sister Dolorosa, 12 June 1971 , SSMO Archives.

190Sister Elizabeth to Sister Dolorosa, 30 June 1971 , SSMO Archives.

191 Mother Angela to Sister Dolorosa, 17 July 1971 , SSMO Archives. 
Durling the evenling of the 27 th members of all schools had a procession with lighted lanterns of various designs which they had made from colored tissue paper. After this, we had Bingo, roulette, and $r$ ing tosses in a booth sponsored by the Parents' Club of the primaria. These games continued through the 28 th and 29 th, day and evening. Parades, races, sports games, etc. kept us occupied during both days.192

The long-term economic effects of the flood were seen in Iquitos in the month of August:

One notices the high prices of things in Iquitos and wonders how the poor can eat. So many live in Belen- in river shacks and often several famil les together. Stealing has increased and you don't wonder why. I (Sister Elizabeth) walked by the employment office yesterday and the men filled the sidewalk for a block and even part of the street. They are digging for petroleum up river and many have jobs as a result of this new find.193

In September, the teachers went on strike for higher wages:

To give you an idea of the justlfication of their action- when we arrived her in 1967 the value of the sol was 26.8 to the dollar. Now (1971) it is roughly 43 . Naturally the cost of living has risen considerably but there has been no increase in teachers' salaries. We lend our support to our colleagues; they need all of the support they can muster.194

192Mother Angela to Sister Dolorosa, 1 August 1971 , SSMO Archives.

193 Sister Elizabeth to Sisters and Friends, 18 August 8, 1971, SSMO Archives.

194 Sister Katerl to Sisters, Families and Friends, September 1971, SSMO Archives. 
The strlke ended by the end of the month.

The missionaries were anxious to participate in the selection process of delegates to the Chapter of Renewal. The distance and the delay in postal service were frustrating. They sent some replies by certified mail in an attempt to get information back quickly enough.195 Sister Kateri suggested that the delegate ballots be mailed first to the missionaries so they could get them back before the final election.196 The final election was held on November 28.

Sister Dolorosa, their closest tie to the community, continued to send weekly notes, newsletters and books to the missionaries to keep them abreast of community, national and international trends. The latest package of books contained Ugly American, Race Against Time by Dom Helder Camara and Shadow of Suspicion.197 After reading the Ugly American, the sisters were convinced of the image Amer icans had. 198

195 Sister Kateri to Sister Dolorosa, 9 October 1971 , SSMO Archives.

196 Ibid.

197 Sister Agnes to Sister Dolorosa, 7 November 1971 , SSMO Archives.

198 Sister El izabeth to Sister Dolorosa, 14 November 1971, SSMO Archives. 
Slster Katerl's health deterlorated. She had a cyst caused by arthritis removed from her wrist in May. By November, two more growths had been removed, the last one from her elbow. She went every Friday after her last class to Iquitos for injections.199

Sister Agnes risked her health by visiting Mr. Varquez, a man in the village who was paralyzed as a result of leprosy of the bone:

At times the man has ulcerations on his feet caused by the leprosy. Mr. Varquez makes $f$ ish nets and hammock when I visit. I usually bring magazines and food. There is very little danger of getting this disease if one is careful about washing their hands thoroughly after shaking hands and handling things he has made.200

There were fourteen people who had leprosy in the village; the sister visited only three of them. Sister Agnes remembers the people with leprosy as some of the happlest people she ever met in the jungle.201

The economic outlook improved with the discovery of oil on November 15 by an American oil company in Tromperteros, an hour away by plane from Tamshiyacu. It

199 Ibid.

200 Sister Agnes to Sister Dolorosa, 7 November 1971 , SSMO Archives.

201 Sister Agnes, personal interview, 22 June 1990. 
was such an exciting event that a school holiday was called.202

The next few weeks were busy as the village prepared for a visit from the Head of the Education Office.

He also was to inaugurate the new High School in Tamshiyacu which is not completed at present. Last Sunday morning all of our thousand children kindergarten through high school--stood waiting for over 5 hours for the General's visit. The General of Education failed to arrive by $4 \mathrm{p} . \mathrm{m}$. so Sister Betty (Sister Elizabeth) and her commission served the luncheon that had been prepared for $\mathrm{him}$ and his assistants to the teachers.203

Even after four years of seeing the sisters work, teach and pray among them, the people turned back to the "religious" practices of the past:

Hermano Jose da Cruz, as he is called, is a gentleman about 59 who cures people with herbs and other medications, also reads a lot from the Bible, baptizes, performs matrlmony, ceremonles, hears confession and holds liturgical services. His liturgical services last for about four hours. Some people say 'Hermano Jose' performs the Mass in a way it used to be in the 'early days'. Hermano Jose is supposed to perform miracles by curing the sick. During the week this Brother was in Tamshiyacu no miracles were performed and one of his followers actually died!! By the way, I took several pictures of Hermano Jose with different cameras without the permission of the Brother hence, the people say the pictures will not come out. (We'll see!) At

202Sister Agnes to Sisters, Friends and Benefactors, 28 November 1971, SSMO Archives.

203 Ibid. 
present we have a large cross in the square to remind the people Hermano Jose was here.204

The school year was winding down. The slsters recelved word from the Education office that the primarla had to have classes until December 30 and graduation had to take place during the first week in January; the high school could close in the middle of December and graduation would take place around December 20.205 The sisters were looking forward to celebrating Christmas for the first time together on December 25! Because of home visits, they had always postponed their celebrations until March.206 Sisters Katerj and Agnes were planning to travel during vacation while Sister Elizabeth and Mother Angela planned to spend most of their time in Lima.207

204 Ibid.

205Mother Angela to Sister Dolorosa, December 1971, SSMO Archives.

206 Sister Elizabeth to Sister Dolorosa, 14 November 1971, SSMO Archives.

20 Mother Angela to Sister Dolorosa, 19 January 1972. SSMO Archives. 


\section{CHAPTER $X$}

THE FINAL YEAR AT THE MISSION

Sisters Katerl and Agnes traveled to Qulto, Ecuador, for their vacation. Travel was very inexpensive; it only cost $\$ 3$ to go on an ocean voyage.208 They enjoyed seeing a display of muslcal Instruments pecullar to Ecuador, from the most primitive to modern ones. 209 Mother Angela finished the government forms by the middle of January 1972.

All of her papers were accepted on the first try! Final grades were requlred to be hand copled and without error; erasures were not permitted. Because the paper was of such poor quality, it absorbed the ink and it sometimes looked like someone had trled to wrlte over $1 \mathrm{t}$; only perfect coples were accepted.210 Sister Elizabeth's bronchitis was acting up again; she was looking forward to vacationing with Mother Angela in Lima in February.211

208Sister Kateri to Sister Annunciata, 1 February 1972, SSMO Archives.

209 Ibid.

210 Sister Elizabeth to Sisters, Friends and Relatives, 19 January 1972, SSMO Archives.

211 Ibid. 
A new pastor, Father Bonaventure, was coming to the village to replace Father Kennard who was asked to returnto the Portland Archdlocese. Whenever a priest was unavallable, the sisters took turns offlciating at the religious services. Sister Katerl had four funerals and two emergency baptisms and conducted the Liturgy of the Word services durling her vacation.212 The new mission team also included three young Peruvlans, one seminarian and two catechists, one young woman and a young man. 213 One of the men taught in the high school and was the director of a youth center that was beginning in the village; the second man visited outside of the village gettling study groups started; the young woman held adult Bible study groups and youth sesslons and also prepared couples for the sacrament of Matrimony.214 The sisters were impressed by their dedication and spirit. As the months went by, the sisters realized that the future of the Church in Peru depended upon the laity; the relatively few religious vocations alone could not meet the needs of

212 Sister Agnes to Sister Annunciata, 28 February 1972, SSMO Archives.

213 Sister Kateri to Sister Annunciata, 6 April 1972 , SSMO Archives.

214 Sister Elizabeth to Sisters, Friends and Relatives, 21 May 1972, SSMO Archives. 
the people.215 The missionaries were interested in the results of the electlon of the Chapter delegates. There was tension within the community as it tried to adapt its traditions and way of life accordlng to the decrees of Vatican Council II. Many slsters had left because changes were not happening quickly enough; others were afrald that the changes threatened their way of $11 \mathrm{fe}$. It was a very difficult time in the community's history. The Chapter delegates had the responsibllity to elect the Superior General and her council, to examine proposals on varlous topics such as habit, communlty life and apostolate, to discuss the pros and cons of each proposal and to vote on them. The Chapter decisions set the direction for the next five years.

The missionaries were sensltive to the tension and unrest within the communlty:

Please know that we are praying, and fervently, for the Chapter developments and that the growing unrest $c$ an be resolved in the best interest of everybody. Makes me (Sister Kateri) think of the cover of Sisters Today 'Llfe is Fragile, Handie with Prayer'.216

In your letter you mentioned there have not been more meetings because as a whole the community is afraid. Sr. Delores, couldn't you talk to

215 Sister Agnes to Sister Dolorosa, 24 November 1972. SSMO Archives.

216sister Kater: to Sister Annunciata, 1 February 1972, SSMO Archives. 
Sister Ermel Inda and Sister Alberta (two Chapter delegates) and see if they would come up with some solutions to save more of our Sisters leaving the communlty. It is sad to see more leave.217

Mother Angela was elected as a delegate and made plans to return to Oregon in late Apr 11 to participate in the election of the Superior General on May 7 and to participate in the Chapter on June 30, July 1-2, 7-8, 21-23. She had some reservations and concerns of her own:

It will be sort of difflcult to take part in chapter, after having been away for so long and with a limited knowledge of what has been happening. All I can say is that the Holy Spirit will have to work overtime in my behalf. It is important for the sake of the mission that our needs be aired to the chapter. 218

Sister Kateri replaced Mother Angela as principal of the primary school.

The enrollment for the primary school was up to 332 students; there were 98 first graders alone.219 Even though the building was not completed, the high school students moved into seven classroom on the first floor in April. On May 9, the village celebrated the fifth anniversary of the high school in style:

217 Sister Agnes to Sister Dolorosa, 2 February 1972 , SSMO Archives.

218 Mother Angela to Sister Dolorosa, 16 March 1972 , SSMO Archives. 
It began with a Mass to the Holy Spirit followed by a program planned by teachers and students.

In the afternoon, a parade of all of the teams

in their sport uniforms inltiated an

inter-school tournament. The P.T.A. sponsored a dance, open to the public to culminate the week. 220

Sister Ellzabeth was seeing the frults of her efforts with the young boy, named Jefferson, who had polio. He was back in the village and enrolled in school for the first time in his life. Because he could not walk yet, his uncle made a wheelbarrow to transport Jefferson to school each day.

The older students take him to and from school and he is so eager to learn that he is far ahead of the others. On Mother's Day he made His First Holy Communion and last Eriday he flew to Lima for his treatments. This in only an answer to prayer- your prayers as there are hundreds of children in Iquitos with polio. Now we have the other 6 children signed up from our village who also have polio.221

The sisters started a program to help feed boys who came from a oistance to go to the high school:

They often $f$ ind a small shack to live in or get a sleeping space (one could not call it a room) from someone and then must do their own washing, cooking and getting firewood and water ! Two years ago, one almost died of starvation and was in our clinic for two weeks. Since then, we

220 Sister Elizabeth to Sisters, Relatives and Friends, 21 May 1972, SSMO Archives.

221 Ibid. 
glve work to the boys on Saturday and in return we pay a lady to give them a good meal every noon. Morning and evening they get their own meal. 222

Improvements were made on the high school. Sister Elizabeth appealed to the P.T.A. and to the mayor for assistance. One of the critical needs was to have a fence around the building because the animals that roamed freely in the village made the school home at night!

Sister Agnes was due to celebrate her Sllver Jubllee in the community; she planned to celebrate on August 15 in Tamshiyacu. In her generous spirit, she wanted little for herself, a new Bible and a camera.223 She wrote to spread the word that: "If anyone would ask what I would like--I would prefer money for library books and science materlal for our high school".224

Word reached the mission that Mother Angela would arrive during the first part of August with a companion, Sister M. Alberta. During the Chapter discussions, Mother Angela asked if any of the sisters would be able to visit the mission to evaluate the schools. Sister M. Alberta did not volunteer immediately. As Director of Schools for

222 Ibid.

2235ister Agnes to Mother Consilia, 20 July 1972, SSMO Archives.

224 Sister Agnes to Sister Dolorosa, 24 June 1972. SSMO Archives. 
the community, she was the most likely volunteer but she wanted a little time to think it over; the next morning, she volunteered. Slster Alberta spent two weeks at the mission experiencing the day to day life of the sisters and visiting the schools. Sister M. Alberta also interviewed each sister privately during her stay. The conferences gave the sisters the opportunity to voice their concerns and needs.

Sister Kateri expressed interest in continuing her work with Spanish-speaking people. She was discouraged at the lack of personnel in the school. She felt her health was $11 \mathrm{miting}$ her actlvitles. She asked for treatment on her feet, the source of her problem at the time. She wanted to come to Oregon for treatment in December and remain until May, thus having ample time for testing and treatment .225

Sister Agnes Coussens was concerned about the Peruvian government's "New Reform" that was to take effect in March 1973; part of the reform would require a Peruvlan to be the director of a school. Sister relied on the oplnion of a priest from a neighboring mission. The prlest believed that education by forelgners would last only two more years because of government restrictions.

225 Sister Alberta, Notes, ms., August 1972, SSMO Archives. 
Sister believed that at least one year was necessary for splrltual, physical and educatlonal rehabllitation.226

Sister Ellzabeth was also concerned about the "New Reform" as she would lose her position as Director. She wondered about the support from the parents for the sisters. The best option for the future, in her opinion, was to train lay Peruvian catechists to work among the people. 227

Mother Angela wanted to stay at the mission as long as posslble. She was discouraged by the conflict between the demands of her position and the lack of time to do everything. The government was supervising the schools more closely than in the past. 228

Sister M. Alberta returned to the Motherhouse with slides and stories to tell after her two weeks in the Jungle, She forwarded the Intormation from the conferences to Mother Consilia and the Council.

On October 18, Mother Consilia sent two letters to Peru, the first one to Sister Katerl asking her to come

226 Ibid. 227 Ibid. 228 Ibid. 
home for complete medical testing. Mother also wrote:

Sister dear, at this time, I feel I must tell you that you should prepare yourself mentally to remain in the states when you come home in December. I know how long it takes to gather together personal belongings when you have been stationed at a place for six years. My prayers will be with you. 229

The second letter was to all four missionarles:

We have given our mlssion in Tamshiyacu much prayer, thought and consideration.

The Council and myself were very grateful that each of you were so open and honest regarding the mission when you had visitation with Sister Mary Alberta. We admire, esteem and appreciate your deep dedication to the poor of Peru. But our love and concern for each of you, for your spiritual and physical well-being has to be weighed against the dedication of working in Peru. After hearing Sister Mary Alberta's report, we feel that the work of the Church in Peru, should be in the hands of lay Peruvians, and that our sisters be withdrawn from the mission as soon as they feel it can be done. We will present our feelings to the General Chapter when it meets in November.230

Just two days after Mother Consilia's letter was written, Mother Angela got terribly sick at the mission; she had a fever and severe abdominal paln for three days before the sisters sent her to Iquitos for a check up.231

229Mother Consilia to Sister Kateri, 18 October 1972, SSMO Archives.

230 Mother Consilia to Sisters, 18 October 1972, SSMO Archives.

231Sister Elizabeth to Mother Consilia, 28 October 1972, SSMO Archives. 
The doctor could not ldentlfy the source of the infection and suggested that she return to the Unlted States for treatment. The other three misslonarles discussed the situation and decided that it would be best to send both Mother Angela and Sister Kater I back together. The plan was to send them to Lima on November 4 to complete the paper work and then fly to the United States a week later .232

The new plan was difficult for Sister Kateri to accept because it meant leaving the mission six weeks earlier than originally scheduled. Many activities, such as preparing the first graders for their First Communion, would have to go on without her. It was an emotional time for her: she could only tell a few people that she was leaving. Before she left, she had a formal "adoption ceremony" for her dog Roo; she didn't want to leave him without someone to take care of him.233 Mother Angela's condition improved to the point that she felt well enough to send a letter to Mother Consilia to "assure you that you will not be meeting a corpse at the airport".234

232 Ibid.

${ }^{233}$ Sister Kateri, personal interview, 22 June 1990.

234Mother Angela to Mother Consilia, 29 October 1972 , SSMO Archives. 
Sisters Agnes and Betty (Elizabeth) wrote letters to Mother Consilia offering options to closing the mission. Sister Agnes hoped for replacements for SIster Kateri and Mother Angela. If the mission was to close, she wanted to "stay on a year longer to help organize the work we have been doing so others can replace us".235 The regional superior of the Marists Sisters came to visit the mission. Sister Betty suggested that if replacements were not available from the Sisters of St. Mary, "perhaps Sr. M. (Sister Agnes) and I could remain to work with the Marists."236 Both remaining missionaries wanted Sister Kateri to speak to the Chapter and present an argument for maintaining the Mission. Little did they realize that Sister Kateri was so physically and emotionally exhausted upon her return, she felt unable to speak to the Chapter. Mother Angela was put in isolation at St. Vincent's Hospital for four days and remained in the hospital during Chapter. 237 Thus, the Chapter would have to make the decision without any further input from the missionaries.

235Sister Agnes to Mother Consilia, 30 Octaber 1972 , SSMO Archives.

236sister Betty to Mother Consilia, 5 November 1972 , SSMO Archives.

237Mother Consilia to Sisters Agnes and Betty, 21 November 1972, SSMO Archives. 
The Vlcar Apostollc, Lorenzo R. Gullbord, O.F.M., In Iquitos, sent a letter to Mother Consilia expressing his concern for the Mlssion:

Mother Angela's and Slster Katerl's departure is quite a blow for the Tamshlyacu Misslon. Worse, I am aware that you may not have any personnel to replace them. Thls would possibly jeopardize even the Mission's existence. 238

He asked that Sisters Betty and Agnes be allowed to remain at the Mission to join with the Marist Sisters, who were expressing interest in the mission, "In an inter-Community 'Sorority" .239 He also expressed his gratitude for "your Sisters' presence and charity during these generous years and sometime very trying circumstance". 240

The Chapter voted on November 25,1972 to close the mission. Mother Consilia's letter containing the Chapter's decision reached Sister Betty in Iquitos on December 4 that the Chapter voted to close the mission. She was able to trust in the decision of the Chapter:

Pray now so we can leave wi thout too much heart-ache. Deep down- I think I am really glad because I know I am very tired physically. If

238 Lorenzo R. Guilbord to Mother Consilia, 1 November 1972, SSMO Archives.

239 Ibia.

240 Ibid.

241 Sister Betty to Mother Consilia, 5 December 1972 , SSMO Archives. 
there are no replacements- I know that I must give up. I have loved my work and the people and it will be hard to leave them but I am sure we'll have the grace necessary at the needed moment. 241

Sister Agnes' letter to Mother Consilla echoed the same willingness to accept the decision:

When we leave in the New Year, Sister Betty and I will feel sad but we realize we can't be carried away by our feelings, also when a person is in a place for six years there is a certain amount of attachment. 242

Sister Agnes wrote Mother Consilia about their plans to stay at the mission until February, getting everything in order and then take a vacation before returning to Oregon. 243

The Marists Sisters were waiting for word from Rome about available personnel for the Mission; there were two or three who were ready to come. 244 The missionaries had many questions about what to pack and what things to leave as they made the final preparations for departure. Sister Betty asked that some of the money left in the donation fund be used to finish the clinic for the

242 Sister Agnes to Mother Consilia, 10 December 1972 , SSMO Archives.

243 Ibjd.

244 Sister Betty to Mother Consilia, 2 January 1973 , SSMO Archives. 
people.245 The clinic was reopened after two years; two nurses helped the sisters clean and organlze the medical supplies. 246

As the final weeks slipped by in Tamshiyacu, the sisters recelved some exciting news: Jefferson would return to the village in March walking with crutches and elght of the graduates from the high school were golng on to college preparatory classes. Two Marist sisters arrived on March 24.247 At the farewell celebration on March 25, the mayor presented the sisters with certificates of outstanding achievement. 248 Two days later, the missionaries left Tamshiyacu for the last time. Many of the children of the village accompanied the sisters to the boat ramp. They spent the next three days in Iquitos; Sister Betty had some dental and doctor appointments to keep and they also visited some friends. Sister Betty was not able to sleep well: "Keep seeing faces before me saying good-bye and crying. I do hope I

245 Ibid.

246 Sister Elizabeth, Diary, ms., January 1973, SSMO Archives.

247 Ibid., 24 March 1973.

248 Ibid., 25 March 1973. 
can be brave at the airport tomorrow." 249 Members of the mission team were at the alrport. During the flight to Lima, neither sister talked much. 


\section{CHAPTER XI}

\section{EPILOGUE}

Sisters Betty and Agnes spent the next six weeks traveling around Latin Amerlca, resting and completing medical exams. They returned to Lima on May 14 to annul their papers for Peru. They left Lima on the next day and arrived in San Francisco on May 16. They were greeted by some members of their families. On May 18, they arrived in Portland and were greeted by Mother Angela and Sisters Kateri and Delores; their missionary journey ended.

Each of the missionarles needed some time to make the transition back to life in the United States. Sister Kater I found the first few weeks back to be a very emotional time. Everything at the Motherhouse seemed so different. She did not look forward to answering questions. After a few days at the Motherhouse, she left to spend time with her parents. She also visited some of the sisters who were teaching in Spokane. In January, she had surgery on her foot; in the spring, she had surgery on her wrist. She recuperated at the Convent of Our Lady of Good Counsel in Milwaukie. In the fall of 1973, she returned to teaching at St. Matthew's School in 
Hillsboro. After one year, she moved to Our Lady of Sorrows School in Portland. She is presently teaching at St. Agatha's School in Portland. 250

Mother Angela's medical condltion Improved. It took several weeks before the doctors realized that she had a severe attack of diverticulitis, a condition she had had before she went to Peru. After her release from the hospital, she spent time visiting her family and the sisters in Ashland, Oregon. In January, she went to Christ the King Grade School in Milwaukie to help with the library and clerical work. She did not feel able to return to the classroom. While working at Christ the King, she was asked by Brother Thomas, the principal at La Salle High School, if she would be interested in helplng in the Counseling Department. She remained at La Salle for the next nine years.251 Sister is enjoying her retirement in residence at St. Agatha's Convent in Portland.

Shortly after Sisters Betty and Agnes returned in May, all the missionaries were sent to a directed retreat at Immaculate Heart Retreat House in Spokane. Sister Betty spent the summer taking nine credits hours at

250 Sister Kateri, personal interview, 22 June 1990 251 Sister Angela, personal interview, 22 June 1990. 
Portland State Unlversity to renew her Oregon teaching certificate. In the fall, she was asked to be the principal at St. Mary's Grade School in Stayton. Her father, who lived in the area, was quite 111 . Sister remalned there for several years before beglnning her current work with Hispanic people in Washington County.252 Sister Agnes spent the summer preparing to work in the grade school residency program at St. Mary of the Valley. After several years, she was asked to be the treasurer of the Motherhouse, a position she continues to hold at the present. 253

252sister Ina Marie, personal interview, 22 June 1990 253 Sister Agnes, personal interview, 22 June 1990. 


\section{CHAPTER XII}

\section{CONCLUSIONS}

It is difficult to evalute the positive and negative results of the missionary effort of American priests, religious and laity who answered the call of Pope John XXIII in 1961. In some respects, the American effort was similiar to the "spiritual conquest" of Latin America by the Spanish centuries earlier. Personnel and money were directed to implant a particular interpretation of the Catholic falth on the native people.

The American experlence of the Catholic Church emphasized structure. both the hierarchical structure of Church government and physical structures; the vast majority of parishes had a rectory, convent. church and grade school. Spirituality included devotional services but the dominant celebration of falth was the Mass every Sunday. By 1960, Catholicism in the United States had "come of age" and was optimistic about its ability to contribute to both the church and the state. The "can do" attitude and the impression that American know-how could solve any problem quickly permeated the early days of mission activity. Latin American Catholics were supposed 
to repeat the historical experlence of American Cathollcs. The changes in the Amerlcan society and the "revolution" initiated by Vatican II shattered the optimism and threw American Catholics into a crisis; the crisis has been described as a crisls in relevance, a crisls of authorlty, a crisis in identity or a crisis of faith.254 In the midst of this crisis, the papal plan fell short of its original goals.

The number of volunteers never came close to the ten-percent level even during the height of the program in 1968.255 Many of the buildings built with American donations are now vacant. The clinic at Tamshiyacu never reopened under the Marist sisters and the high school was made into an Agricultural school.256 Three of the main objectives of the papal plan had limited sucesses: evangelization of the people, fostering native vocations and stemming the communist threat. 257

The people of the village of Tamshiyacu had a profound, simple faith. They relied on the providence of

254John Tracy Ellis, "The Church in Revolt: the tumultuous sixties." The Critic, January-February 1970 , 21.

255 Gerald M. Costello, Mission to Latin America, 231. 256 sister Ina Marie, personal interview, 22 June 1990. 257 Costello, Mission to Latin America, 231. 
God for everything. In their own way, they were close to God and had a reverence for anything assoclated with their faith. Even though the parents were pleased with the opportunity their children had for learning more about their religion, the religious practices of the "early days" continued to be a part of the life of the village. For special feasts, such as Chrlstmas and Easter, the people spent hours preparing for and participating in elaborate pageants and plays; when the program was finished, they often left to go home without going to Mass. The sisters were troubled by this practice because it was so different from their experience in the United States.

During the six years the sisters were in Peru, there was not a single mentlon of a natlve prlest or religlous. No mention was made of a young man or woman from the village entering religious life or priesthood. A critical factor for the lack of interest was the requirement of celibacy; children were an essential part of life for the people of the village and the people never fully understood why the sisters never had children of their own. As the sisters were preparing to leave, their hope for the future of the Church in Peru was with the lay people. 
The vlllage was far removed from the realm of polltlcs. Communlsm was not a real concern of the slsters. They dld have some direct contact with communlsm In the vlllage: the superintendent of the Agricultural School was a Marxist and two of the best and brightest high school boys were glven scholarships to study in the Soviet Union. 258 The sisters were not affected by the political situation in Peru except in the area of education; they were required to follow all the regulations sent out by the office of Education.

Not all the results were negative however. Two exciting, unexpected developments gave meaning and hope to the Church in Latin America. The first, was the maturation of a uniquely Latin American experience of church; the second was the internationalization of the American Church.259

The lajty was taking on greater significance in the I ife of the Church in Latin America in the late 1950's. Lay catechists became responsible for the religious life of a small group of people called a base community. Instead of building structures, churches, rectories, etc.,

258 sister Ina Marie, personal interview, 22 June 1990.

259Gerald M. Costello, Mission to Latin America: The Successes and Failures of a Twentieth Century Crusade.. 231 
meeting halls were built to be used as schools, places of religlous instruction, sewing lessons and meetings to discuss community problems.260 Thus the faith life of the people was no longer dependent on the availability of a priest.

By 1957, the Church was becoming "one of the strongest forces for social and economic change" in Lat in America.261 There was a growing realization among some of the hierarchy that:
A man can be so poor and oppressed, so much outside society, that he has no chance really to be a Christian. His economic and social position must be improved before he has a spiritual opportunity.262

Because of their involvement in the economic and social issues of their people, priests were arrested in Peru on the grounds that they were "aiding extreme leftists". 263

Pope Paul VI's encyclical. Populorum Progessio on March 26. 1967 also had political overtones. He emphasized the relationship between $r i c h$ and poor

260Leonardo Boff, Ecclesiogenesis: The Base Community Reinvents the Church (Maryknol), New York: Orbis Books, $1986), 3$.

261 "Changing Role of the Church in Latin America," S. News and World Report, 16 October 1967: 94 .

262 Ibid.

263 Ibid. 
countries polnting out that if inequalitles continued, there was the distinct danger that the poor wlll resort to violence.264 The encyclical was severely attacked by many Latin American businessmen.265 Pope Paul continued to support the efforts of the Latin Amerlcan hlerarchy by being the first pope in the history of the Church to go to Lat in America by attending the Second General Conference of Latin American Bishops at Medillin, Colombia in August 1968. The purpose of the conference was to have findings of Vatican II adapted to Lat in America by Latin Americans. The Conference sent the message that Church in Latin America could chart its own future.

The missionaries shared in this new experience of Church. They accepted responsibllities that were reserved only for priests in the United States: baptisms, communion services, funerals and encouraged the lay catechists in their efforts. The sisters supported and even joined

264Michael Walsh and Brian Davies, eds., Proclaiming Justice and Peace: Documents from John XIII to John Paul II (Mystic, Connecticut: Twenty-Third Publications, 1985), 177 .

265 "Changing Role of the Church in Latin America," U. S. News, 95. 
their teachers during a strike for salary increases.266 There was a growing awareness that the Church needed to commit itself to the poor.

American Catholics were drawn out of their parochlal If ife into the larger experlence of the global church as the missionaries returned with stories and slides of the conditions of people all over Latin America. Many school children in the Archdiocese of Portland in Oregon had bake sales and other activities to assist the missionaries, who were their former teacher or relative, in their work among the poor. Although the number of missionaries to Latin America has decreased in recent years, their works and lives continue to link Catholics together.

The Sisters of St. Mary of Oregon, to date, have never returned to the mission of Tamshiyacu but remain linked to it, in spirit, because of the dedicated efforts of Sisters Angela, Kateri, Agres and Ina Marie. There is a heightened awareness of events in Peru that continues today within the community almost twenty-four years after they departed from the Motherhouse on their journey to the mission. Some may question the personal sacrifices each of the missionaries made, but the missionaries are reluctant to mention any hardship. In their hearts, 
nothlng was too great to rlsk for the people of Tamsh i yacu. 
I. Secondary Works

A. BOOKS

Boft, Leonardo, Ecclesiogenesis: The Base Commurity Reinvent the Church. Maryknoll, New York: Drbis Books. 1986.

Costelio, Gerald M. Mission to Iatin Amerlca: The Successes and Fallures of a Twentieth century crusade. Maryknoll, New York: Orbis Books, 1979 .

Dolan, Jay P. The Amerlcan Cathelic Experience: A History from Colental Times to the Present. Garden City, New York: Doubleday and Company, Inc., 1985.

Drury, John, trans. Between Honesty and Hope: Documents from and about the church in Lat in Amecica. Maryknoll, New York: Maryknoll Publlcatlons, 1969.

Gutierrez, Gustavo. A Theology of Liberation, Maryknoll, New York: Orbis Books, 1973.

Nei11, Stephen. A History of ChristianMissien. New York: Viking Penguin, Inc., 1964.

Schoenberg, Wilfred P.. S.J. These Valiant Women:

History at the Sisters of St. Mary of oregen. $1836-1986$. Portland, Oregon: Western

Lithograph, 1986.

Walsh. Michael and Davles, Brian, ed. Eroclaiming Jusids and Peace: Documents fom 3 cha XXII to Jonn Paul II. Mystic, Connecticut: Twenty-Thlra Publications, 1985. 
B. MAGAZINE ARTICLES

"A Mission Territory." Newsweek. 18 January 1960, 80.

"Chanaing Role of the Church in Lat in Arner la." U. S. Wevs and Wab d Repors. 16 october 1967, 94-95.

Ejlic. Jonn Trary, "The Church in Fevolt: The Tumultuous Sixties." The Critic January-Eeoruary 1970. $12-21$.

Fesquet. Henci. "The Pope's Opportunity." Tablet 20 Juiy $1968, \quad 714-16$.

Fitzpatrlok, Joseph P. "Bridging a Culture Gap: Training Center at Cuernavaca." Breica 2 February 1962.

Mallon. Vincent T. "High Hopes for Peru." Arerica, 21 May $1950.282-3$.

"Peru: Big winner." Lewsweek, 30 December 1963, 30-31.

"Peru: Revolution Within the Law." Time. 2 October 1964, 71 .

"Peru: The Mllitary Tanes Over." Iine. 2? July 1962, $25-26$.

Plke, Frearlok B. "Churoh and Stare in Peru and Chile

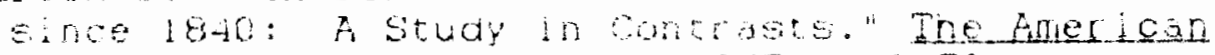
Histardsal Review, Octoper i967. 30-50.

Veremans. Foger F. "Is the Church losing Latin Imerica?" Ave Mardia. 9 Janual": 1960, 5-10.

I1. Primary sources

A. ARCHIVAL REEREENCES

Concli Mirutes $966-1972$. Sisters ot 3 . Mary of oregon Archives, Beaverton. Cregon. 
Coussens, Sister Agnes to Sister Dolorosa, 21 May 1968-24 November 1972. Sisters of St. Mary of Oregon Archives, Beaverton, Oregon.

General Chapter Minutes, 1972. Sisters of St. Mary of Oregon Archives, Beaverton, Oregon.

Lehman, Sister Angela to Sister Dolorosa, 23 May 1968-9 April 1972. Sisters of St. Mary of Oregon Archives, Beaverton, Oregon.

Nosack, Slster Elizabeth. Dlary, ms. 8 August 1966- 18 May 1973. Sisters of St. Mary of Oregon Archives, Beaverton, Oregon.

Nosack, Sister Elizabeth to Sister Dolorosa, 1 March 196725 January 1973. Sisters of St. Mary of Oregon Archives, Beaverton Oregon.

Petite, Sister Kateri to Slster Dolorosa, 2 December 19582 February 1972. Sisters of St. Mary of Oregon Archives, Beaverton, Oregon.

\section{B. NEWSPAPER ARTICLES}

"Archdiocesan Mission Ministers to the Splrltual, Temporal Needs of Peruvian Villagers," Catholic Sentinel [Oregon] 27 September 1968, sec. A: 13-16.

"Catholic Nuns Fight Poverty, Ignorance as Teachers in Peru," Oregonian [Oregon] 24 February $1969 \mathrm{sec}$. A: 10 .

"Convent Was Bare: Getting Settled in Peru Has Problems, Sisters Find," Catholic Sentinel [Oregon] 31 March 1967, sec. A: 1,19.

Hogan, Gorman. "Combined Clvlc Center and Hlgh School to Open Soon at Tamshlyacu in Peru: Gifts Aid Building," Catholic Sentinel [Oregon] 18 February 1966 sec. A: 14-15.

Hogan, Gorman. "In the Peruvian Jungle, Church Seeks to Serve the People," Catholic Sentinel [Oregon] 25 February 1966, sec. A: 14-15. 
Hogan, Gorman. "Peruvian Misslon Gives Medlcal Ald in Amazon Jungle," Cathollc Sentinel [Oregon] 11 February 1966 , sec. A: 14-15.

Hogan, Gorman. "Tamshlyacu:'An Insplrational Treat"," Catholic Sentinel [Oregon] 4 February 1966, sec. A: $14-15$.

Levada, William. "Missionaries link us to Latin America," Catholic Sentinel [Oregon] 22 September 1989, sec. A: 5 .

"Oregon Sisters Prepare to Leave for Archdiocesan Mission in Peru," Catholic Sentinel [Oregon] 5 August 1966 , sec. A: 1,25 .

"Peru Mission Doing Well, But Needs Still Exist, Reports Returning Nurse" Catholic Sentinel [Oregon] 8 September 1967 , sec. A: 21 .

"Report From Tamshiyacu: Parents Gladly Sacrifice To Send Children To Peru Mission School," Catholle Sentinel [Oregon] 23 February 1968, sec. A: 18.

"School Classes At Home Were Never Llke Thls," Catholle Sentinel [Oregon] 9 June 1967, sec. A: 19.

"Sisters From County Schools Assigned to Peruvian Mission," Hillsboro Arqus [Oregon] 9 June 1966, sec. $A: 10$.

"Sisters Leave for Peru Mission," Catholic Sentinel [Oregon] 19 August 1966, sec. A: 1.

"Sisters of St. Mary of Oregon Will send Nuns to Peru Mission," Catholic Sentinel [Oregon] 18 March 1966 , sec. A: 1,28 .

"Superior Visits Mission: Oregon Sisters In Peru Happy, Love the Work," Catholic Sentinel [Oregon] 29 November 1968, sec. A: 1, 24.

"Tamshiyacu: Beaverton Nurse Joins Misslon," Catholic Sentinel [Oregon] 14 March 1969, sec.A: 1, 23.

"Three Sisters Appointed to Work At Archdiocesan Mission in Peru," Catholic Sentinel [Oregon] 10 June 1966, sec. A: 1, 21 . 